\title{
JUVENTUDE POR COR E RENDA \\ NO ACESSO AO ENSINO SUPERIOR \\ Somando desvantagens, multiplicando desigualdades?
}

\section{Felícia Picanço}

Universidade Federal do Rio de Janeiro (UFRJ), Rio de Janeiro - RJ, Brasil. E-mail: felicia@uol.com.br

DOI: http//dx.doi.org/10.17666/3088145-179/2015

\section{Introdução}

A partir dos anos de 1990 o Brasil experimentou a crescente expansão do acesso à educação fundamental, média e superior, acompanhada por um conjunto de políticas públicas e programas sociais de incentivo a ampliação de vagas e acesso nos diferentes níveis do sistema educacional e à manutenção das crianças e jovens no processo de escolarização. Um dos resultados, além da quase universalização do ensino fundamental, é o aumento e a diversificação da demanda e oferta do ensino superior, aqui enfatizados. $\mathrm{Na}$ demanda, há o crescimento de jovens que concluem o ensino médio, proporcionalmente maior em grupos sociais em desvantagens, em especial negros e pobres. $\mathrm{Na}$ oferta, há a expansão das vagas no ensino privado e público através da criação de novas instituiçôes de ensino superior

Artigo recebido em 22/10/2013

Aprovado em 28/11/2014
(IES), campi e cursos, redução dos preços das mensalidades nas IES privadas (Sampaio, 2011) e programas sociais voltados para o acesso de candidatos de baixa renda, negros e indígenas a IES privadas e públicas. Ainda assim, o ingresso dos jovens de um modo geral é restrito se comparado a outros países. Apesar disso, a composição dos matriculados vem mudando com a maior presença dos estudantes negros e de baixa renda (Neves, 2007; Neves, Morche e Anhaia, 2011).

Aos estudiosos de estratificação e desigualdades cabe analisar em que medida a expansão e a diversificação incidem no aumento ou na redução das desigualdades sociais, seja por proporcionar mais oportunidades para os indivíduos em posições de desvantagem, seja por ampliar as oportunidades, para os indivíduos em posições de vantagem (Silva, 2003; Arum, Gamoran e Shavit, 2007).

As teorias explicativas da relação entre expansão educacional e desigualdades foram desenvolvi- 
das mais intensamente a partir das transformações ocorridas na educação secundária no período em que passa da educação de elite para a educação de massa. As perspectivas teóricas, modelos analíticos e autores que estimularam o desenvolvimento da área são identificados segundo o processo que marca a estratificação educacional e os achados empíricos dos seus estudos. São elas: a perspectiva da industrialização, ou meritocrática, que incorpora autores como Treiman (1970), Parsons (1970), Hauser e Featherman (1976); a perspectiva da reprodução social, com suas diferentes matrizes, mas em especial Bourdieu e Passseron (1974), Bowles e Gitis (1976) e Collins (1979); e a perspectiva da escolha racional, constituída na esteira de autores como Boudon (1981), Goldthorpe (1996), Rafetry e Hout (1993) e Lucas (2001).

A perspectiva da industrialização postula que quanto maior desenvolvimento social e econômico, menor o efeito da origem social sobre as trajetórias e resultados em termos educacionais e ocupacionais. A educação se expande promovendo a equalização dos indivíduos em termos de oportunidades educacionais e aquisição de valores culturais, logo, os indivíduos estariam em posiçôes mais igualitárias de competição e suas realizações dependeriam do mérito e do investimento pessoal. Muitos estudos internacionais e nacionais apontam as limitaçōes dessa perspectiva em fornecer ferramentas analíticas para a interpretação, explicação ou compreensão das tendências contemporâneas, o que reduz seu uso à construção de hipóteses que são rejeitadas.

Em um campo oposto, a perspectiva da reprodução pode ser expressa por aquilo que une as diferentes contribuições que a compõem: o sistema educacional não é produtor de igualdade de oportunidades, mas reprodutor e produtor de desigualdades. Bourdieu e Passeron (1974), representantes significativos dessa perspectiva, constroem sua análise postulando que a educação promove desigualdades na medida em que é um sistema constituído por seleçôes sucessivas, cujos "testes" são formulados por aqueles que estão nas posições de vantagem na hierarquia social. Os mais aptos são, então, aqueles que mais se aproximam do capital cultural e linguístico do grupo dominante. O resultado é que estudantes com origens nas classes sociais em situação de vantagem têm mais probabilidade de passar nas seleçôes.

Enquanto os estudos empíricos sobre o processo de expansão educacional apontavam na direção da manutenção das desigualdades, de um lado, e a crítica à perspectiva da reprodução social emergia, de outro, as saídas teóricas que vêm ecoando nos estudos mais recentes acionam a perspectiva da ação racional em suas diferentes vertentes.

A construção de Breen e Goldthorpe (1997), identificada como relative risk aversion (RRA), toma Boudon (1981) como referência e argumenta, contra o culturalismo desse autor, que a aquisição de escolaridade deve ser entendida a partir de dois tipos de efeitos e não apenas das aspirações socialmente construídas. Os efeitos primários vêm da posição social da família, uma vez que a posição ocupada pelos pais cria uma diferenciação no desempenho escolar das crianças (nível de habilidade) e nas suas aspirações. Estabelece-se, assim, uma correlação entre nível escolar e posição social, na qual as crianças das classes em situação de desvantagem têm menores níveis de habilidade do que aquelas em situação de vantagem. Os efeitos secundários vêm da avaliação que os pais em suas posições sociais fazem do risco, do benefício e do custo da continuidade de aquisição dos níveis de escolaridade. Os efeitos se combinam na medida em que tal avaliação está diretamente vinculada à percepção do nível de habilidade das crianças e expectativas de sucesso.

Goldthorpe (2007) não deixa de enfatizar a distância que separa sua construção da perspectiva da reprodução, em especial, os escritos de Bourdieu acerca da transmissão social do capital cultural através do habitus, que habilita uns e não outros para a competição no sistema de ensino. Segundo o autor, trata-se de uma noção supersocializada dos indivíduos que não leva em consideração as evidências empíricas de casos como a Inglaterra no qual o processo de expansão educacional permitiu a aquisição de melhores níveis educacionais e capital cultural das crianças da classe trabalhadora, portanto, não apenas reproduz o capital cultural, mas também o cria. Não obstante a manutenção dos níveis de desigualdades, agora transferidas para a educação superior, a noção de habitus calcada da transmissão familiar é insustentável. Tais observa- 
çôes críticas são fundamentais para serem resgatadas, porque os estudos que se seguem não fazem referência direta a Bourdieu e o debate teórico que envolve todas as perspectivas não confronta diretamente seus argumentos.

O estudo de Raftery e Hout (1993) analisa os dados educacionais da Irlanda e concluem que quando o sistema educacional expande, não o faz apenas para as classes em desvantagem: a expansão é para todos, e os indivíduos mais bem preparados e equipados das classes em vantagem são os mais aptos a aproveitar as novas oportunidades. Desse modo, é possível manter as desigualdades mesmo em um contexto de expansão. Os grupos em desvantagem só ampliam as chances de ingresso em um determinado nível quando o grupo em situação de vantagem já atingiu seu ponto de saturação - maximally maintained inequality (MMI). Embora a MMI identifique o padrão, ela não o explica. Segundo os autores, as apostas na continuidade do processo escolar ou a saída dele explicam-se por uma avaliação de custo e benefício realizada pelos indivíduos e suas famílias que envolve, em especial, a perda salarial por se manter no processo de escolarização, os custos monetários da educação e o valor atribuído aos benefícios culturais da educação.

Breen e Jonsson (2000) trouxeram nova contribuição ao inserirem um aspecto decisivo para as análises de estratificação educacional: a diferenciação qualitativa do sistema educacional. Os indivíduos não escolhem apenas sair ou continuar nas transições educacionais, mas optam também entre os tipos de cursos existentes, e para cada caminho possível existe uma probabilidade distinta de segui-lo. Os autores concluem que os efeitos de classe na probabilidade de transição variam de acordo com a escolha feita em relação aos caminhos vocacional ou acadêmico escolhidos.

A terceira contribuiçãa foi o estudo de Lucas (2001), identificada pela hipótese de effectively maintained inequality (EMI). O autor argumenta que, uma vez ocorrida a saturação em um determinado nível, a desigualdade das chances de alcançar aquele nível pode ser substituída pela desigualdade das chances de alcançar um caminho mais seletivo. Desse modo, a diferenciação qualitativa do sistema permite que haja uma redução quantitativa da de- sigualdade de acesso a um determinado nível educacional, mas sustenta o acesso desigual a caminhos mais seletivos dentro do mesmo nível.

Em uma análise sobre a consistência científica das hipóteses de, RRA, MMI e EMI, Lucas (2009) conclui que, enquanto a RRA e a EMI são formalmente científicas, pois são falsificáveis, a MMI não respeita esse critério. O exercício analítico do autor permite concluir que o ponto de saturação, elemento central da hipótese, não é algo fixo ou calculável, consequentemente, não se pode negar ou aceitar que um ponto de saturação foi alcançado pelos grupos em vantagem e a entrada dos grupos em desvantagem tenha sido assim possibilitada. Além disso, conclui o autor, há uma relação possível de ser estabelecida entre a RRA e a EMI, porque cada uma enfatiza diferentes aspectos do processo sem negar a outra: enquanto a RRA ilumina o voluntarismo dos indivíduos sem ignorar os constrangimentos, a EMI ilumina os constrangimentos sem negar o voluntarismo.

No entanto, sob a perspectiva teórica da escolha racional, em termos de identificação dos padrões, os resultados obtidos por meio das três hipóteses referidas não deixam de equivaler à construção geral da reprodução e da distinção presentes nos escritos de Bourdieu. São osrecursos explicativos para dar conta da reprodução das desigualdades ou mudanças ao longo do tempo que colocam tais análises em campos diversos.

No Brasil, a análise sobre estratificação educacional acompanhou o desenvolvimento da área. Os estudos de Silva (2003), Ribeiro (2007; 2011), Mont'Alvão (2011) e Marteleto, Carvalhaes e Hubert (2012), usando bases de dados e metodologias distintas, traçam um grande panorama da relação entre as perspectivas teóricas, modelos analíticos e hipóteses da literatura internacional e dos dados brasileiros. Apesar dos investimentos desses e outros autores, a limitação dos dados é digna de nota, pois a pesquisa que oferece maior chance de acompanhamento longitudinal, a Pesquisa Nacional por Amostra de Domicílio (PNAD), só fez a pergunta sobre origem social em anos cujo suplemento foi o tema da mobilidade social - e o último ano foi 1996. Portanto, com base nos censos e nas PNADs, a análise dos impactos da escolaridade ou da ocupa- 
ção dos pais nas transições educacionais dos indivíduos só pode ser processada para aqueles que estão na condição de filhos.

Silva (2003) analisa a relação entre a estratificação e a expansão educacional para as transições da primeira, quarta e oitava séries em 1981, 1990 e 1999 utilizando o modelo logístico. Os dois critérios de análise dos dados são a variação dos efeitos das variáveis nas transições para cada ano e a comparação entre os efeitos das variáveis nas transições ao longo do tempo. $\mathrm{O}$ autor sugere que a quase universalização do acesso ao ensino básico transfere a seletividade para as outras transições, o que é coerente com o argumento de que a condição para o declínio dos efeitos de origem se estabelece uma vez que os grupos em vantagem atingiram a saturação nesse nível, de acordo, portanto, com a hipótese da MMI.

Ribeiro (2011) faz um estudo sobre as transições educacionais a partir da pesquisa Padrões de Vida, realizada pelo Instituto Brasileiro de Geografia e Estatística (IBGE) entre 1996 e 1997 seguindo o modelo analítico de Gerber e Hout (1995). Os resultados corroboram mais uma vez a hipótese da MMI, pois a expansão do ensino primário e secundário ocorrida a partir dos anos de 1970 permitiu que, com o acesso dos grupos em vantagem já garantido, as crianças de outras origens pudessem ampliar seu acesso. Como não foi acompanhada pela expansão das vagas no ensino superior, a maior oferta de jovens com ensino médio completo tornou o acesso mais competitivo e, nesse contexto, os jovens cujas mães tinham escolaridade mais elevada tinham maior vantagem. Sobre a raça, o autor ainda aponta que o seu efeito é menor do que o da classe, mas, enquanto o da classe reduz, este é constante em todas as coortes estudadas e maior na conclusão de um ano de universidade. Isso significa que o efeito não cede nem com a expansão educacional mencionada anteriormente.

Mont'Alvão (2011) analisa as chances de realização da transição do ensino médio e da transição do ensino médio para a educação superior considerando a divisão entre ensino público e privado. Segundo suas análises, a educação dos pais e renda per capita têm efeitos positivos nas transições na rede de ensino pública e privada, logo, não asseguram um caminho específico. Desse modo, corrobora a rejeição da hipótese que emerge da perspectiva teórica da industrialização, rejeição já presente em Silva (2003) e Fernandes (2005), pois não há sinais de avanço da meritocracia. Abre-se espaço para analisar os dados tanto pela perspectiva da reprodução quanto pela aplicação do modelo ou hipótese da MMI, reduzindo-se a possibilidade de compreendermos o caso brasileiro a partir da EMI.

Marteleto, Carvalhaes e Hubert (2012), em estudo comparativo sobre Brasil e México para jovens de 15 a 18 anos, evidenciam o peso da qualidade diferenciada do sistema educacional, utilizando como fator de qualidade o ensino público ou privado (os testes medem de forma clara a diferença). Os autores concluem que a expansão favoreceu a redução do peso da origem social na transição dos jovens para o secundário em função da ampliação da escolaridade dos filhos de pais em desvantagem. Ao longo do tempo, porém, houve até mesmo um aumento da associação entre pais em vantagem e matrícula no ensino privado, o que permite corroborar a hipótese da EMI.

O que há em comum entre esses estudos, com exceção de Marteleto, Carvalhaes e Hubert (2012), que não analisaram o efeito da raça em função da limitação dos dados - é que, mesmo levando a classe ou renda familiar em conta, a desigualdade racial desempenha um fator determinante, ainda que em queda, nas transiçôes escolares. Os achados nos remetem não apenas à tradição dos estudos de relações raciais no Brasil, que se consolidaram no enfrentamento do debate de raça versus classe, e mais contemporaneamente das análises e debates públicos sobre as políticas de ação afirmativa no ensino superior. Acompanhando a literatura de estratificação educacional, as mudanças na oferta da educação superior e a redução das desigualdades raciais e de renda no Brasil, este artigo tem como objetivo analisar o quadro da desigualdade de chances no acesso ao ensino superior dos jovens de 18 a 29 anos segundo raça e renda, a partir dos dados da PNAD (1993, 1998, 2003 e 2011) e da análise das razões de chances. ${ }^{4}$

$\mathrm{Na}$ primeira parte, serão apresentadas as mudanças na demanda por ensino superior no Brasil, na oferta e no perfil dos estudantes do ensino superior. 
Nesse item, enfatizaremos o aumento da aquisição escolar no nível médio para os grupos sociais historicamente em desvantagem, os programas públicos de acesso ao ensino superior e o crescimento da participação dos negros e mais pobres universitários. $\mathrm{Na}$ segunda parte, analisaremos o que fazem os jovens de 18 a 29 anos em termos de trabalho e estudo, seu acesso ao ensino superior e as desigualdades entre os grupos de cor e de renda.

\section{Demanda e oferta no ensino superior no Brasil}

\section{Mudanças na demanda por educação superior}

O Brasil sustentou por muito tempo péssimos indicadores de acesso à escolarização, além de elevadas desigualdades entre grupos de cor e renda (Hasenbalg e Silva, 1999; 2000; Henriques, 2001). As reformas ocorridas nas décadas de 1960 e 1970 não foram capazes de gerar grandes alterações do ponto de vista da quantidade, muito menos da qualidade do ensino, em especial do público. As mudanças tiveram como resultados expressivos a expansão do ensino privado no nível primário e secundário e criação do vestibular. Uma combinação que se tornou perversa na medida em que o investimento privado nos níveis primário e secundário e o escasso investimento nas escolas públicas tornaram os egressos das escolas privadas mais bem preparados para a seleção no vestibular. Ao mesmo tempo, a falta de expansão de vagas no ensino superior restringiu significativamente o acesso à universidade de grupos sociais em desvantagem socioeconômica. Mesmo havendo, no período de redemocratização do país, durante os anos de 1980, a ampliação dos investimentos dos governos estaduais na educação básica, não se investiu igualmente na abertura de vagas no ensino superior (Ribeiro, 2007; Neves, 2007; Neves, Morche e Anhaia, 2011). O resultado foi ambíguo, afinal, uma vez que ao lado da quase universalização do acesso e aumentou a competição pela universidade.

Nos anos de 1990 e 2000 podemos identificar projetos e programas que tiveram um grande impacto seja na continuidade da ampliação do acesso à educação básica, seja na expansão das vagas no ensino superior. No âmbito da educação básica destaca-se a criação do Fundo de Manutenção e Desenvolvimento do Ensino Fundamental e de Valorização do Magistério (Fundef), implantado em 1998,5 que determinou a distribuição dos recursos com base no número de estudantes atendidos pelas diferentes redes estaduais e municipais ao estabelecer um valor mínimo por aluno. Além disso, $60 \%$ do orçamento deveria ser utilizado para o pagamento do salário dos professores. Castro (1999) indica que o critério utilizado para a distribuição dos recursos fiscais acabou por estimular a realização do maior número possível de matrículas pelos sistemas de ensino.

Soma-se a essa política, os programas sociais cuja condicionalidade ou o objetivo fim é a frequência escolar das crianças e adolescentes, implementados pelos governos federal, estadual e municipal. No governo do presidente Fernando Henrique Cardoso (1995-2002), os destaques foram o Programa de Erradicação do Trabalho infantil (Peti), iniciado em 1996, e o Programa Bolsa Escola do governo Federal implementado nacionalmente em 2001. Em 2003, o então presidente Luís Inácio Lula da Silva instituiu programa Bolsa Família com o objetivo de unificar e ampliar programas já existentes.

$\mathrm{Na}$ segunda metade dos anos 2000, é criado o Fundo de Manutenção e Desenvolvimento da Educação Básica e de Valorização dos Profissionais da Educação (Fundeb), em substituição ao Fundo de Manutenção e Desenvolvimento do Ensino Fundamental (Fundef), que vigorou de 1998 a 2006. O Fundeb passou a incluir a educação infantil e o ensino médio.

A configuração no fim da década se caracteriza pela rápida ampliação da demanda por ensino superior. Segundo os dados da PNAD, em 2011, $26,3 \%$ da população brasileira acima de 18 anos tinha o ensino médio completo, ${ }^{7}$ um percentual que 15 anos antes era $11 \%$ (Tabela $A$, anexa).

$\mathrm{O}$ maior acesso ao ensino médio teve um impacto fundamental na redução das desigualdades entre os grupos de cor e renda. Em 1993, entre os brancos acima de 18 anos, 13,2\% tinham o ensino médio completo e entre os negros o percentual era 7,8\% (Tabelas B e C, anexas), resultando em quase 
dois brancos para um negro (razão de chances de 1,8). A ampliação ao longo do tempo se deu entre os dois grupos, chegando em 2011, com os percentuais de $27,8 \%$ e $24,8 \%$, respectivamente.

A desigualdade de renda é chocante, pois, em 1993, apenas 2,0\% dos indivíduos acima de 18 anos do quintil mais pobre tinha ensino médio completo, percentual esse que sobe para $22 \%$ quando se trata do quintil mais rico (Tabelas D e E, anexas). Em 2011, os percentuais passam para $15,1 \%$ e $29,7 \%$, respectivamente.

O Gráfico 1 ilustra a queda na razão de chances $(\mathrm{RC})$ dos brancos e negros $(\mathrm{Br} / \mathrm{Ng})^{8}$ e entre os indivíduos no primeiro quintil de renda $\left(1^{\circ} \mathrm{q}\right)$, o mais pobre, e no quinto quintil $\left(5^{\circ} \mathrm{q}\right)$, o mais rico, em ter o ensino médio completo. A queda das desigualdades entre brancos e negros é contínua e aponta que estamos muito próximos da igualdade. Entre os mais ricos e pobres, apesar da sua elevada magnitude, há uma brusca redução. Mesmo em queda, concluímos que no âmbito do ensino médio, a renda produz uma desigualdade maior entre os jovens do que a cor, mas a expansão educacional, as dinâmicas do mercado de trabalho (requisitos de escolaridade para preenchimento das ocupações e dinâmicas de abertura e redução das oportunidades ocupacionais) e a valorização cultural dessa aquisição certamente têm favorecido a continuidade do no processo de escolarização para todos.

Os dados apresentados podem esconder as desigualdades qualitativas, isto é, tipos de escolas diferenciadas escolhidas pelos grupos que estão em vantagem. Logo, em termos das hipóteses que aqui acionadas para compreender as desigualdades, é possível interpretá-los à luz tanto da hipótese MMI quanto da EMI; isto é, quantitativamente temos a redução das desigualdades pela saturação do grupo em vantagem na aquisição do ensino médio, mas desigualdades qualitativas estão sendo produzidas.

A comparação entre brancos e negros dentro dos quintis é um dado que nos oferece a chance de observar dimensões relevantes das desigualdades apontadas. Em 1993, 2,8\% dos brancos e 1,6\% dos negros acima de 18 anos no quintil mais pobre ti-

\section{Gráfico 1}

Razão de Chances de Ter Ensino Médio Completo na População Brasileira acima de 18 anos, Brancos / Negros e $1^{\circ} / 5^{\circ}$ quintil

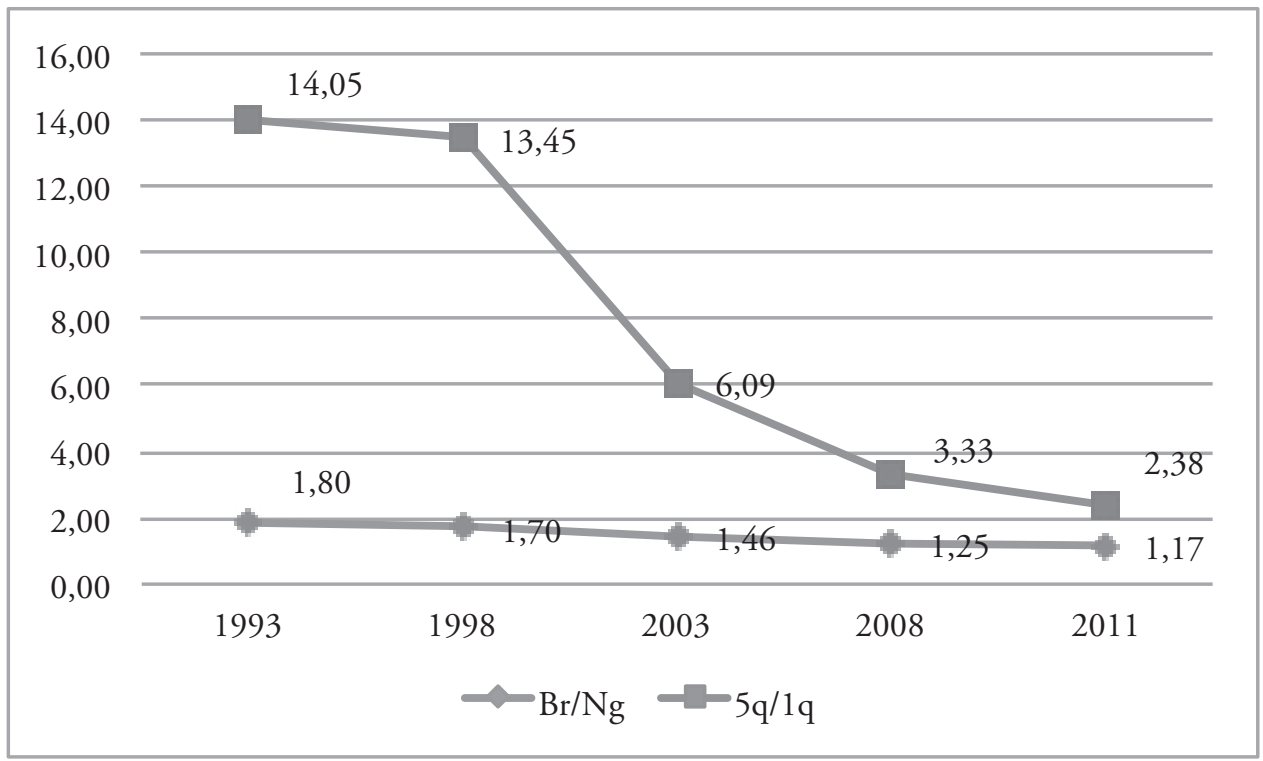

Fonte: PNAD/IBGE, tabulação própria. 
nham ensino médio completo, enquanto no quintil mais rico ambos percentuais era $22,1 \%$ (Tabelas $\mathrm{F}$ a $\mathrm{O}$, anexas), evidenciando que a maior desigualdade entre brancos e negros estava nos mais pobres e a igualdade entre os mais ricos, pois, como se pode observar no Gráfico 2, a desigualdade nos demais quintis variou entre esses polos.

Ao longo do tempo, no entanto, a desigualdade reduziu nos quintis mais pobres e nos intermediários. No quintil mais rico, o percentual dos negros com ensino médio completo supera o dos brancos (Tabelas $\mathrm{N}$ e $\mathrm{O}$, anexas), pois os brancos estão se dirigindo mais para o ensino superior; consequentemente, a razão de chances fica abaixo de um. Se, entre os mais ricos, os dados permitem corroborar a hipótese MMI, em que os grupos em desvantagem só ampliam as chances de ingresso em um determinado nível quando o grupo em situação de vantagem já atingiu seu ponto de saturação, entre os mais pobres não há subsídios para tanto, pois a renda, embora em franca redução, é um elemento central nessa aquisiçãa.
O resultado é que, em 2011, o cenário dos anos de 1990, no qual maior a renda, menor a desigualdade entre brancos e negros, se altera. As maiores desigualdades encontradas nas chances de ter o ensino médio completo entre brancos e negros estão nos polos, isto é, entre os mais ricos e os mais pobres, só que com dominância invertida: entre os mais pobres os brancos estão em vantagem e entre os mais ricos, os negros estão em vantagem (Gráfico 2).

Embora os dados aqui analisados não tenham sido tratados de modo a testar hipóteses, indicamos que a desigualdade em queda para os grupos de cor e renda pode ser efeito da saturação dos grupos em vantagem, mas pode obscurecer diferenças qualitativas nas escolhas escolares realizadas. Essas interpretaçōes provocam a pergunta: se a demanda por educação superior se expande de maneira surpreendente e com grupos sociais cada vez mais diversificados, potencialmente disponíveis para tal aposta, como contemplar a diversidade na demanda? A resposta é: por meio da oferta de uma educação superior cada vez mais diversificada e de estímulos, passaportes e suportes para viabilizar tal aposta.

\section{Gráfico 2}

\section{Razão de Chances de Ter Ensino Médio Completo entre Brancos e Negros nos Quintis de Renda na Populaçáo Brasileira acima de 18 anos}

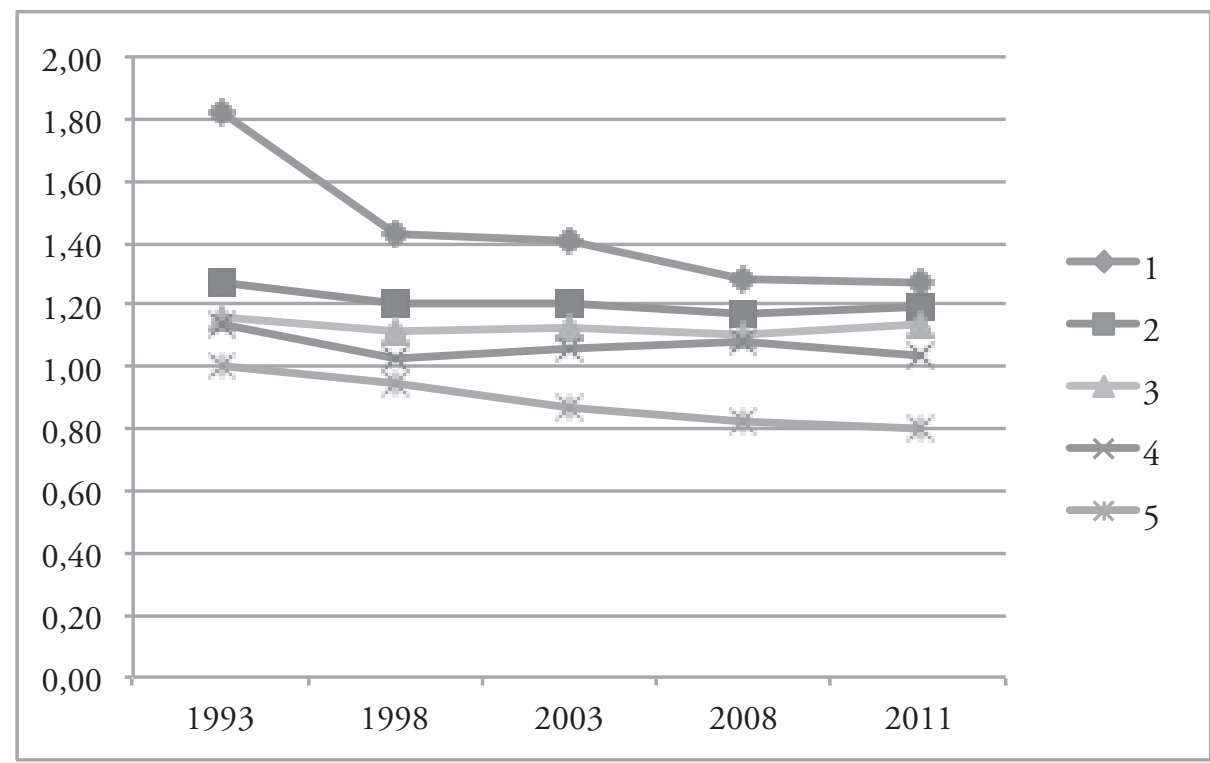

Fonte: PNAD/IBGE, tabulação própria. 


\section{Diversificação institucional e programas públicos}

Neves (2012) faz um grande mapa do sistema educacional superior no país e destaca que o Brasil consolidou seu sistema de educação superior com dois segmentos distintos: um público, funcionando a partir de instituiçôes públicas (federais, estaduais e municipais); outro privado, composto por instituiçōes confessionais, particulares, comunitárias e filantrópicas. Os cursos de graduação oferecem formação presencial em bacharelado, licenciatura e tecnológico. Os cursos de pós-graduação incorporam especialização, mestrado, doutorado nos formatos acadêmico e profissional, e assistem ao surgimento de um novo segmento, o curso a distância.

A expansão se deu em momentos distintos e com questões muito específicas para cada um deles. O primeiro momento é identificado da década de 1960 até a de 1980, quando o governo federal concedeu autorização para a criação de estabelecimentos privados, sem qualquer vinculação com pesquisa para dar conta da demanda das classes médias que tinha na educação superior o passaporte para a ascensão e reprodução social.

Não obstante a efervescência na sociedade civil, os anos de 1980 se caracterizam pelos péssimos indicadores econômicos e sociais - entre os quais as poucas vagas criadas na educação superior.

Os anos de 1990 foram decisivos ao conjugarem processos de desregulamentação do trabalho, privatizaçōes, altos índices de desempregos e plano de estabilização econômica. A reorientação da política econômica levou ao novo momento de expansão através da criação de vagas nos estabelecimentos privados e diversificação dos cursos (Neves, 2007; Prates, 2007; Comim e Barbosa, 2011).

Também foi nesse período que as primeiras demandas políticas pela adoção de programas e sistemas de inclusão social para os grupos de cor nas universidades emergem dentro de um contexto nacional e internacional de tematização das relaçōes raciais marcadas pelo efeito da preparação para a Conferência Mundial contra o Racismo, Discriminação Racial, Xenofobia e Intolerância Correlata, em Durban, África do Sul, e das pesquisas que evidenciaram as desigualdades raciais no acesso ao mercado de trabalho e à educação superior (Queiroz e Santos, 2007).
O fim da década de 1990 e os anos 2000 se destacam pelo estímulo, fortemente marcado pela Conferência de Durban, ao preenchimento das vagas criadas no setor privado e à criação de vagas no setor público através da abertura de novos cursos e universidades - em especial o Programa de Apoio a Planos de Reestruturação e Expansão das Universidades Federais (Reuni) - e programas públicos de inclusão dos grupos em desvantagem.

Os programas públicos de inclusão social na universidade aqui considerados são aqueles que estimulam ou favorecem o ingresso de grupos sociais que estão em desvantagens socioeconômicas no ensino superior: Fundo de Financiamento ao Estudante do Ensino Superior (Fies); programas de reserva de vagas ou bônus para grupos de cor, etnia ou renda; o Programa Universidade para Todos (Prouni); e o Programa Diversidade na Universidade (PDU).

O Fies foi criado em 1999 em substituição ao Crédito Educativo (Creduc) pelo governo federal, sob a presidência de Fernando Henrique Cardoso e o ministério de Paulo Renato de Souza na Educação. Ao longo dos anos 2000, o Fies sofreu algumas mudanças e se vinculou ao Prouni, criado em 2004, e passou a estabelecer que podem se candidatar bolsistas parciais de $50 \%$ do Prouni, estudantes beneficiários de bolsas complementares matriculados em cursos considerados prioritários, estudantes beneficiários de bolsas complementares matriculados nos demais cursos, estudantes matriculados em instituiçōes de educação superior que tenham aderido ao Prouni e estudantes matriculados em IES que não tenham aderido ao programa.

Os programas de reserva de vagas para os grupos sociais em desvantagem no ensino superior, como mencionado, ganharam força primeiro como demanda no período de preparação da Conferência Durban, segundo como experiência no período posterior a ela. As primeiras experiências foram nas universidades estaduais do Rio de Janeiro -Universidade do Estado do Rio de Janeiro (Uerj) e Universidade Estadual do Norte Fluminense (Uenf) -, por força da lei sancionada pelo então governador Anthony Garotinho, e na Universidade Estadual da Bahia (Ufba), por uma iniciativa institucional. A partir daí iniciativas em outras IES foram sendo construídas com distintos modelos. Essa descentralização das 
iniciativas, embora favorecesse a adequação do formato às demandas locais, por outro lado dificultava a visibilidade das iniciativas e a avaliaçôes nacionais e não favorecia a resolução de problemas concernentes à concepção, planejamento e execução (Daflon, Feres Jr. e Campos, 2013).

Os levantamentos das modalidades de açôes afirmativas até 2012 segundo os grupos contemplados mostram mais de $80 \%$ das instituições adotavam reserva de vagas ou bonificação para alunos egressos da escola pública (cotas sociais), quase 60\% para negros e $51 \%$ para indígenas (cotas raciais) (Idem). Contabilizando de outra forma, Santos, Souza e Sasaki (2013) identificaram que $44 \%$ (55 instituições) as políticas são combinaçōes entre cotas sociais e raciais, $40 \%$ (cinquenta instituiçōes), 11\% (catorze instituiçōes) cotas raciais - estas, dividas entre nove com cotas exclusivamente para indígenas e cinco para negros e indígenas, além de $5 \%$ para deficientes.

O quadro mudou bastante com a Lei n. 12711, sancionada em agosto de 2012 pela presidente Dilma Roussef, que determinou que as instituiçōes de ensino superior e médio federais devem reservar $50 \%$ de vagas para alunos da escola pública. As universidades terão quatro anos para chegar até $50 \%$, iniciando com 12,5\%. Metade das vagas reservadas para escola pública deverá ser dirigida para estudantes com até 1,5 salário mínimo de renda familiar per capita e as vagas reservadas deverão ser distribuídas de acordo com a proporção de negros e indígenas na população. Em 2013 a lei já estava em vigor.

O exercício analítico proposto por Carvalhaes, Feres Jr. e Daflon (2013) sobre o impacto da Lei de Cotas federal nos estados conclui que os maiores beneficiados serão os grupos com renda familiar per capita acima de 1,5 salário mínimo, e destes, os pretos, pardos e indígenas mais do que os brancos. $\mathrm{E}$ a competitividade maior, o que significa a maior dificuldade para se obter uma vaga no ensino superior, está no grupo que acumula maior desvantagem: negros e indígenas com renda familiar inferior a 1,5 salários mínimos per capita.

O Prouni foi criado pelo governo federal em 2004 e institucionalizado pela Lei n. 11.096, em 13 de janeiro de 2005. O programa é dirigido aos estudantes egressos do ensino médio da rede pública ou da rede particular na condição de bolsistas integrais e tem reserva de vagas para portadores de deficiência, professores da rede pública de ensino e alunos que se autodeclararem afrodescendentes ou indígenas. As vagas para afrodescendentes são distribuídas de acordo com a proporção dessas populaçōes nos estados, tendo como requisito a renda per $c a-$ pita familiar máxima de três salários mínimos. Os candidatos são selecionados pelas notas obtidas no Exame Nacional do Ensino Médio (Enem).

O Programa Diversidade na Universidade (PDU) esteve em atividade entre 2002 e 2007 pelo Banco Interamericano de Desenvolvimento (BID), com cooperação técnica da Unesco. Umas das iniciativas do programa eram os Projetos Inovadores de Cursos (PICs). Os PICs tinham como objetivo principal apoiar cursos preparatórios para vestibular para negros e indígenas e realizou editais em 2003, 2004 e 2005, totalizando oitenta projetos apoiados. Os dados disponibilizados pelo MEC estimaram que, em 2005, participaram do PIC 5375 estudantes de seis estados (Rio de Janeiro, São Paulo, Minas Gerais, Mato Grosso do Sul, Bahia e Maranhão) e que o repasse foi de R \$ 2,9 milhōes (MEC, 2013). Em 2005 e 2006 foram concedidas aos egressos dos PICs bolsas de permanência na universidade através de editais do Uniafro. ${ }^{9}$

Todas as ações (econômicas, políticas e programas sociais) constroem em conjunto o seguinte quadro. Em relação a ofertas de vagas, Neves (2007) sistematizou as informações de que, em 1998, 776.031 vagas foram ofertadas para cursos presenciais, distribuídas entre 205.725 nas IES públicas e 570.306 na privada; em 2010 foram ofertadas 3.120 .192 vagas, distribuídas entre 445.337 nas IES públicas e 2.674.855 na privada. Enquanto o número de vagas no setor público cresceu $116,4 \%$, no setor privado cresceu $369,02 \%$. E mesmo com o número de candidatos crescente, a taxa candidato/vaga cai de 3,7 para 2,1 , sendo que a queda no segmento público foi de 7,8 para 7,6 e no privado 2,2 para 1,2. O resultado é uma queda na taxa de ocupação que passa de $83,9 \%$ para $51,0 \%$ : no segmento público cai de $95,4 \%$ para $91,7 \%$ e no segmento privado, de $79,8 \%$ para $44,2 \%$.

De qualquer forma, comemora-se continuamente o êxito de que o número de matrículas no ensino superior (presencial e a distância) sobe expo- 
nencialmente. Segundo o Inep, em 1993, somavam 1.594.668; em 2000, passou para 2.694.245 e, em 2011, 6.379.299 matrículas.

\section{Números do acesso ao ensino superior}

Mudanças na demanda e na oferta na educação superior produzem novos números no acesso ao ensino superior, e, para mensurar esse contingente, agregamos os alunos com 18 anos ou mais que declaram que tinham nível escolaridade superior (incompleto e completo). Nesse sentido, não estamos lidando apenas com indivíduos que concluíram o nível superior, mas também com aqueles estão cursando ou cursaram e abandonaram, isto é, em algum momento tiveram acesso ao ensino superior.

Em 1993, 7,7\% da população acima de dezoito anos tinham acesso ao nível superior; em 2011, passam para $15,5 \%$ (Tabela A). O efeito contínuo da cor (Ribeiro, 2007) ao longo das transições educacionais resulta que, em 1993, 11,2\% dos brancos e $2,8 \%$ dos negros tiveram acesso ao ensino supe- rior e, em 2011, os percentuais passam para $21,6 \%$ e $9,4 \%$, respectivamente.

No primeiro quintil, em 1993, apenas 0,3\% tiveram acesso ao ensino superior; dezoito anos depois somavam 2,1\%. No quinto quintil, em contrapartida, os percentuais nesses anos foram de $24,3 \%$ para $40,2 \%$.

A ampliação observada teve um impacto importante na redução das desigualdades entre brancos e negros e entre os quintis mais pobre e mais rico medidas pela razão de chances. No Gráfico 3, observamos que entre brancos e negros a magnitude é menor, com a queda já iniciando em 2003. Entre os quintis, até 2003 a tendência era de crescimento da desigualdade entre os mais pobres e mais ricos, certamente um momento de pouca disponibilidade dos mais pobres em aspirar tal percurso e/ou arcar com os custos do ensino superior, em especial o privado. Somente em 2008 a queda se apresenta, de forma brusca.

O Gráfico 4 evidencia que os negros mais pobres avançam a partir 2003, de modo a provocar

\section{Gráfico 3}

\section{Razão de Chances de Ter Nível Superior da População Brasileira acima de 18 anos} Brancos / Negros e 1\%/5 quintil

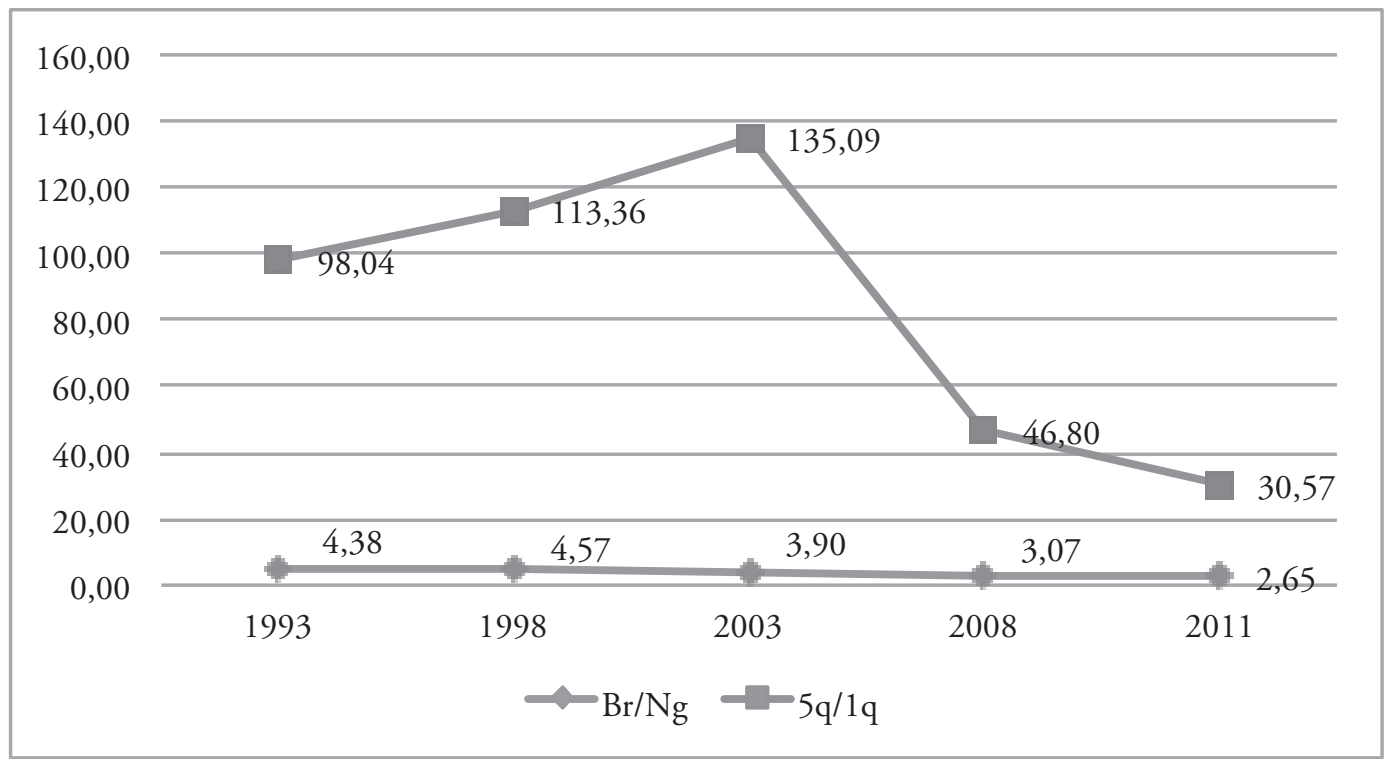

Fonte: PNAD/IBGE, tabulação própria. 
a redução nas desigualdades de cor e raça nesse grupo de renda. Na medida em que a sua renda melhora, as desigualdades caem gradualmente e, ao longo tempo, vão se aproximando nos quintis, o que significa que independentemente de serem um mecanismo de reprodução social ou de ascensão, brancos e negros mantém uma diferença de acesso similar.

A consequência mais direta dessa aproximação é que os programas sociais de inclusão social que em sua larga escala trazem o corte de renda, reforçado com a recente lei de cotas das IES federais, ao deixar os negros com melhores renda de fora começam a errar o alvo dentro do novo contexto. Manter tais programas com o corte de renda implica reforçar o olhar de que a discriminação racial só pode ser tratada dentro do invólucro da desigualdade econômica.

A continuidade da escolarização dos negros e dos mais pobres em maior proporção do que antes está sendo realizado em contexto de acesso ainda muito restrito ao nível superior. Nesse sentido, há sinais de queda das desigualdades sem que estejam acompanhadas de sinais de saturação dos grupos em vantagem.

\section{Que jovens apostam no ensino superior?}

Embora sejam os indivíduos mais velhos que ampliam mais a presença no conjunto dos estudantes (Picanço, 2012), o interesse é analisar a faixa etária em que se localiza a maior parte dos estudantes e candidatos em potencial: os jovens. Determinar a faixa etária que define esse grupo não é simples e implica definiçōes teóricas, processos sociais e convençôes oficiais. A escolha foi por tomar como jovens indivíduos entre 18 a 29 anos, ${ }^{0}$ estendendo faixa para 29 como forma de captar o investimento daqueles jovens que ingressaram tardiamente na universidade. Então, a análise continua identificando o crescimento da demanda por nível superior nessa população, seus destinos escolares e os impactos das mudanças e permanências nas desigualdades dos ne-

\section{Gráfico 4}

Razão de Chances entre Brancos e Negros nos Quintis de Renda na População Brasileira acima de 18 anos

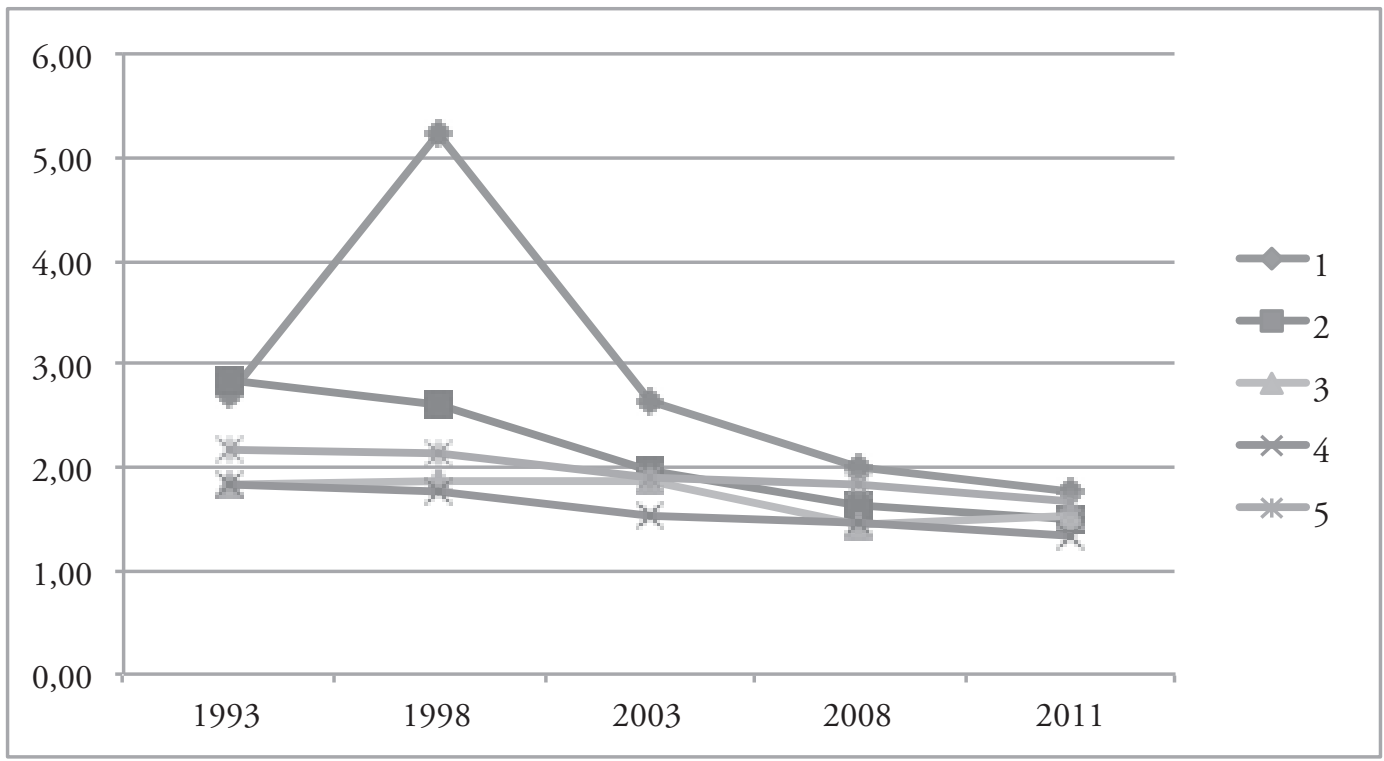

Fonte: PNAD/IBGE, tabulação própria. 
gros e brancos, mais pobres e ricos, como forma de compreender os limites e possibilidades do modelo de expansão desigualmente vivido entre esses grupos.

Os jovens que em 1993 tinham entre 18 e 29 anos estiveram no ensino médio nos anos de 1980; os jovens em 1998, entre anos de 1980 e 1990; os jovens em 2003, nos de 1990 e no começo dos de 2000; os jovens em 2008 e 2011, a partir da segunda metade dos anos de 1990. Cada grupo experimentou distintos contextos em relação à economia e características dos sistemas educacionais, com maior ou menor investimento na educação básica e abertura de vagas no ensino superior, cenários fundamentais para compreender as apostas feitas na educação.

\section{Jovens e a demanda por ensino superior}

Os itens anteriores mostraram que no contexto de expansão do ensino superior e da adoção de programas e sistemas de inclusão nas universidades há um aumento da demanda por ensino superior, considerando apenas o maior número de indivíduos com ensino médio completo e daqueles já no ensino superior. Essas dinâmicas estão acompanhadas da re- dução das desigualdades entre grupos em desvantagem por cor e renda.

Entre jovens, de forma específica, observamos que o percentual com ensino médio completo ampliou de 14,1\%, em 1993, para 38,7\% em 2011. Podemos identificar na Tabela 1 que o aumento mais intenso se deu entre 1998 e 2003.

Por cor, a tendência é a mesma daquela já apontada: aumento do ensino médio nos anos de 1990. Entre os negros, em 1993, 10,1\% e, entre os brancos, $17,4 \%$ tinham ensino médio completo, e passaram, em 2011, para 37,1\% e 40,8\%, respectivamente (Tabelas 2 e 3). No entanto, são os negros que ampliam mais intensamente suas presenças nesses dois níveis de escolaridade.

Por quintil de renda, tínhamos em 1993 2,6\% dos jovens do primeiro quintil, $6,1 \%$ dos jovens do segundo quintil, $10,8 \%$ dos jovens do terceiro quintil, $19,3 \%$ dos jovens do quarto quintil e $28,8 \%$ dos jovens do quinto quintil com o ensino médio completo. Ao longo do tempo, todos ampliam o percentual, mas o maior salto é dado de fato entre 1998 e 2003 , chegando em 2008 aos percentuais de $22,8 \%, 35,8 \%$, $44,7 \%, 49,9 \%$ e $37,8 \%$. Vale lembrar que o menor

Tabela 1

Jovens de 18 a 29 anos Segundo Nível de Escolaridade (\%)

\begin{tabular}{lccccccccc}
\hline \multirow{2}{*}{$\begin{array}{l}\text { Nível de } \\
\text { escolaridade }\end{array}$} & \multicolumn{9}{c}{ Anos } \\
\cline { 2 - 10 } & $\mathbf{1 9 9 3}$ & $\mathbf{1 9 9 8}$ & $\mathbf{2 0 0 3}$ & $\mathbf{2 0 0 8}$ & $\mathbf{2 0 1 1}$ & $\mathbf{9 3 / 9 8}$ & $\mathbf{9 8 / 0 3}$ & $\mathbf{0 3 / 0 8}$ & $\mathbf{0 8 / 1 1}$ \\
\hline - 1 ano & 8,6 & 6,7 & 4,6 & 3,3 & 4,4 & $-22,90$ & $-30,78$ & $-27,35$ & 31,6 \\
\hline Prim. incompleto & 13,8 & 11,2 & 7,5 & 4,1 & 2,6 & $-18,92$ & $-33,27$ & $-45,18$ & $-36,2$ \\
\hline Prim. Completo & 13,5 & 10,4 & 7,0 & 4,3 & 2,8 & $-22,63$ & $-33,33$ & $-38,09$ & $-35,2$ \\
\hline EF incompleto & 22,6 & 22,2 & 17,5 & 13,2 & 10,7 & $-1,98$ & $-20,83$ & $-24,72$ & $-19,0$ \\
\hline EF completo & 11,2 & 11,1 & 10,3 & 10,0 & 10,5 & $-0,67$ & $-7,18$ & $-3,34$ & 4,7 \\
\hline EM incompleto & 8,7 & 11,1 & 12,2 & 12,7 & 12,0 & 27,58 & 9,71 & 3,73 & $-5,5$ \\
\hline EM completo & 14,1 & 18,4 & 28,6 & 36,2 & 38,7 & 30,50 & 55,61 & 26,45 & 7,1 \\
\hline Sup inc/com & 6,9 & 8,1 & 11,3 & 15,7 & 18,0 & 17,31 & 38,85 & 38,72 & 14,8 \\
\hline S/inf & 0,5 & 0,8 & 1,0 & 0,6 & 0,3 & 55,26 & 28,26 & $-42,57$ & $-37,8$ \\
\hline Total & 100,0 & 100,0 & 100,0 & 100,0 & 100,0 & & & & \\
\hline
\end{tabular}

Fonte: PNAD/IBGE, tabulação própria. 
Tabela 2

Jovens Brancos Segundo Nível de Escolaridade (\%)

\begin{tabular}{lccccccccc}
\hline \multirow{2}{*}{ Escolaridade } & \multicolumn{4}{c}{ Percentual } & \multicolumn{3}{c}{ Ampliação/redução } \\
\cline { 2 - 10 } & $\mathbf{1 9 9 3}$ & $\mathbf{1 9 9 8}$ & $\mathbf{2 0 0 3}$ & $\mathbf{2 0 0 8}$ & $\mathbf{2 0 1 1}$ & $\mathbf{9 3 / 9 8}$ & $\mathbf{9 8 / 0 3}$ & $\mathbf{0 3 / 0 8}$ & $\mathbf{0 8 / 1 1}$ \\
\hline - 1 ano & 4,6 & 3,6 & 2,6 & 2,2 & 2,9 & $-22,21$ & $-26,28$ & $-17,01$ & 34,8 \\
\hline $\begin{array}{l}\text { Primário } \\
\text { incompleto }\end{array}$ & 9,6 & 7,4 & 4,5 & 2,3 & 1,5 & $-22,46$ & $-40,19$ & $-49,39$ & $-34,9$ \\
\hline Primário completo & 13,1 & 9,0 & 5,4 & 2,9 & 1,9 & $-30,85$ & $-39,82$ & $-47,44$ & $-34,8$ \\
\hline EF incompleto & 21,9 & 20,2 & 13,9 & 9,4 & 7,5 & $-7,75$ & $-31,00$ & $-32,86$ & $-19,8$ \\
\hline EF completo & 12,4 & 11,7 & 10,2 & 8,8 & 8,7 & $-5,27$ & $-13,31$ & $-13,60$ & $-0,4$ \\
\hline EM incompleto & 10,0 & 11,9 & 11,7 & 11,2 & 10,0 & 19,02 & $-1,79$ & $-4,72$ & $-10,3$ \\
\hline EM completo & 17,4 & 22,7 & 33,1 & 39,1 & 40,8 & 30,23 & 46,18 & 18,03 & 4,4 \\
\hline SUP incom/comp & 10,6 & 12,6 & 17,6 & 23,8 & 26,3 & 18,93 & 39,99 & 35,33 & 10,5 \\
\hline Sem informação & 0,5 & 0,9 & 0,9 & 0,5 & 0,3 & 79,15 & 8,25 & $-47,31$ & $-32,9$ \\
\hline Total & 100 & 100 & 100 & 100 & & & & & \\
\hline
\end{tabular}

Fonte: PNADs/IBGE tabulação própria.

Tabela 3

Jovens Negros Segundo Nível de Escolaridade (\%)

\begin{tabular}{lccccccccc}
\hline \multirow{2}{*}{ Escolaridade } & \multicolumn{4}{c}{ Percentual } & \multicolumn{3}{c}{ Ampliação/redução } \\
\cline { 2 - 10 } & $\mathbf{1 9 9 3}$ & $\mathbf{1 9 9 8}$ & $\mathbf{2 0 0 3}$ & $\mathbf{2 0 0 8}$ & $\mathbf{2 0 1 1}$ & $\mathbf{9 3 / 9 8}$ & $\mathbf{9 8 / 0 3}$ & $\mathbf{0 3 / 0 8}$ & $\mathbf{0 8 / 1 1}$ \\
\hline - 1 ano & 13,4 & 10,2 & 6,6 & 4,2 & 5,6 & $-23,47$ & $-35,26$ & $-35,95$ & 32,1 \\
\hline $\begin{array}{l}\text { Primário } \\
\text { incompleto }\end{array}$ & 18,9 & 15,6 & 10,6 & 5,8 & 3,6 & $-17,43$ & $-31,81$ & $-45,67$ & $-38,0$ \\
\hline Primário completo & 14,1 & 12,1 & 8,6 & 5,6 & 3,6 & $-13,97$ & $-29,36$ & $-34,38$ & $-36,3$ \\
\hline EF incompleto & 23,6 & 24,5 & 21,3 & 16,7 & 13,5 & 3,87 & $-13,18$ & $-21,37$ & $-19,6$ \\
\hline EF completo & 9,9 & 10,5 & 10,5 & 11,1 & 11,9 & 6,40 & $-0,12$ & 5,36 & 7,5 \\
\hline EM incompleto & 7,2 & 10,2 & 12,7 & 14,0 & 13,6 & 42,68 & 24,03 & 10,47 & $-2,9$ \\
\hline EM completo & 10,1 & 13,4 & 24,0 & 33,6 & 37,1 & 32,52 & 79,73 & 40,11 & 10,2 \\
\hline SUP incom/comp & 2,4 & 2,8 & 4,7 & 8,3 & 10,8 & 15,16 & 67,42 & 77,09 & 30,9 \\
\hline Sem informação & 0,5 & 0,6 & 1,0 & 0,6 & 0,4 & 28,55 & 59,02 & $-38,82$ & $-42,9$ \\
\hline Total & 100 & 100 & 100 & 100 & & & & & \\
\hline
\end{tabular}

Fonte: PNADs/IBGE tabulação própria. 
percentual de jovens do quinto quintil com ensino médio completo se deve ao fato de que eles estão mais no ensino superior, indicando a saturação desse grupo (hipótese de MMI) e possíveis apostas em diferenciações como indica Nogueira (1998) e Alves (2010) ao analisar as escolhas escolares das famílias.

A ampliação dos percentuais proporcionalmente maior dos negros e dos mais pobres, tal como já identificado na população de 18 anos ou mais, resulta na queda das desigualdades (Gráfico 5). Da mesma forma, mesmo com a queda brusca da desigualdade de renda, a renda ainda é um fator gerador de desigualdade mais intenso do que a raça.

Em 1993, 3,5\% dos jovens brancos e 2,2\% dos jovens negros no quintil mais pobre tinham ensino médio completo, já no quintil mais rico os percentuais eram respectivamente $29,3 \%$ e $27,1 \%$. Em 2011, os percentuais no quintil mais pobre passam para $13,7 \%$ entre os jovens brancos e $11,1 \%$ entre os jovens negros; no quintil mais rico, para $35,3 \%$ e $39,4 \%$.

A ampliação maior dos negros em todos os quintis incide na redução da desigualdade de raça. E, como foi observado para a população como um todo, no quintil mais rico os negros ultrapassam os brancos indicando a saturação desse grupo (Gráfico 6). O resultado é que nos polos estão as maiores desigualdades. Nesse sentido, não há nenhuma especificidade entre a população jovem de 18 a 29 anos se comparada com população acima de 18 anos.
Se esses jovens que se escolarizam mais formam o novo contingente para estar ou permanecer no ensino superior, quantos de fato estão lá?

\section{Os destinos escolares}

Os jovens analisados neste item são considerados elegíveis para fazer a aposta na educação superior, isto é, com ensino médio completo. O primeiro dado a ser apresentado é a inserção no mercado de trabalho porque a compatibilização trabalho e estudo é um arranjo sempre difícil de ser feito - envolve uma logística em termos de mobilidade urbana, disponibilidade de recursos financeiros e apoios de diversas ordens - em especial para aqueles que tem dependentes (filhos ou outros). Além de o sistema do ensino superior, sobretudo o público, ser muito menos receptivo ao estudante trabalhador, que dispõe apenas do turno da noite para estudar. ${ }^{1}$

O quadro em relação ao trabalho é: no começo dos anos de 1990, cerca 59,6\% dos jovens elegíveis trabalhavam, $7,7 \%$ só estudavam, $13,4 \%$ conjugavam trabalho e estudo, $2,3 \%$ só estudavam, mas procuraram trabalho, $7,3 \%$ só procuraram e 9,6\% nada declararam em relação a trabalho e estudo (Gráfico 5). Até 2003, as tendências foram de: redução daqueles que só trabalhavam e dos que nada declararam em relação a trabalho/estudo; e ampliação dos que conjugavam trabalho/estudo e os procuraram trabalho.

Tabela 4

Percentual dos Jovens com Ensino Médio Completo nos Quintis de Renda(\%)

\begin{tabular}{cccccccccc}
\hline \multirow{2}{*}{ Escolaridade } & \multicolumn{4}{c}{ Percentual } & \multicolumn{4}{c}{ Ampliação/redução } \\
\cline { 2 - 10 } & $\mathbf{1 9 9 3}$ & $\mathbf{1 9 9 8}$ & $\mathbf{2 0 0 3}$ & $\mathbf{2 0 0 8}$ & $\mathbf{2 0 1 1}$ & $\mathbf{9 3 / 9 8}$ & $\mathbf{9 8 / 0 3}$ & $\mathbf{0 3 / 0 8}$ & $\mathbf{0 8 / 1 1}$ \\
\hline $1^{\circ}$ & 2,6 & 3,5 & 9,1 & 17,1 & 22,8 & 34,3 & 161,4 & 88,4 & 33,5 \\
\hline $2^{\circ}$ & 6,1 & 8,4 & 19,2 & 30,5 & 35,8 & 37,0 & 128,6 & 58,4 & 17,5 \\
\hline $3^{\circ}$ & 10,8 & 15,8 & 30,5 & 40,7 & 44,7 & 46,3 & 92,5 & 33,4 & 9,8 \\
\hline $4^{\circ}$ & 19,3 & 26,4 & 42,7 & 49,6 & 49,9 & 37,0 & 61,6 & 16,2 & 0,6 \\
\hline $5^{\circ}$ & 28,8 & 35,3 & 39,8 & 38,5 & 37,8 & 22,8 & 12,6 & $-3,3$ & $-1,6$ \\
\hline
\end{tabular}

Fonte: PNADs/IBGE tabulação própria. 
Gráfico 5

Razão de Chances em Ter o Ensino Médio Completo entre os Jovens de 18 a 29 anos

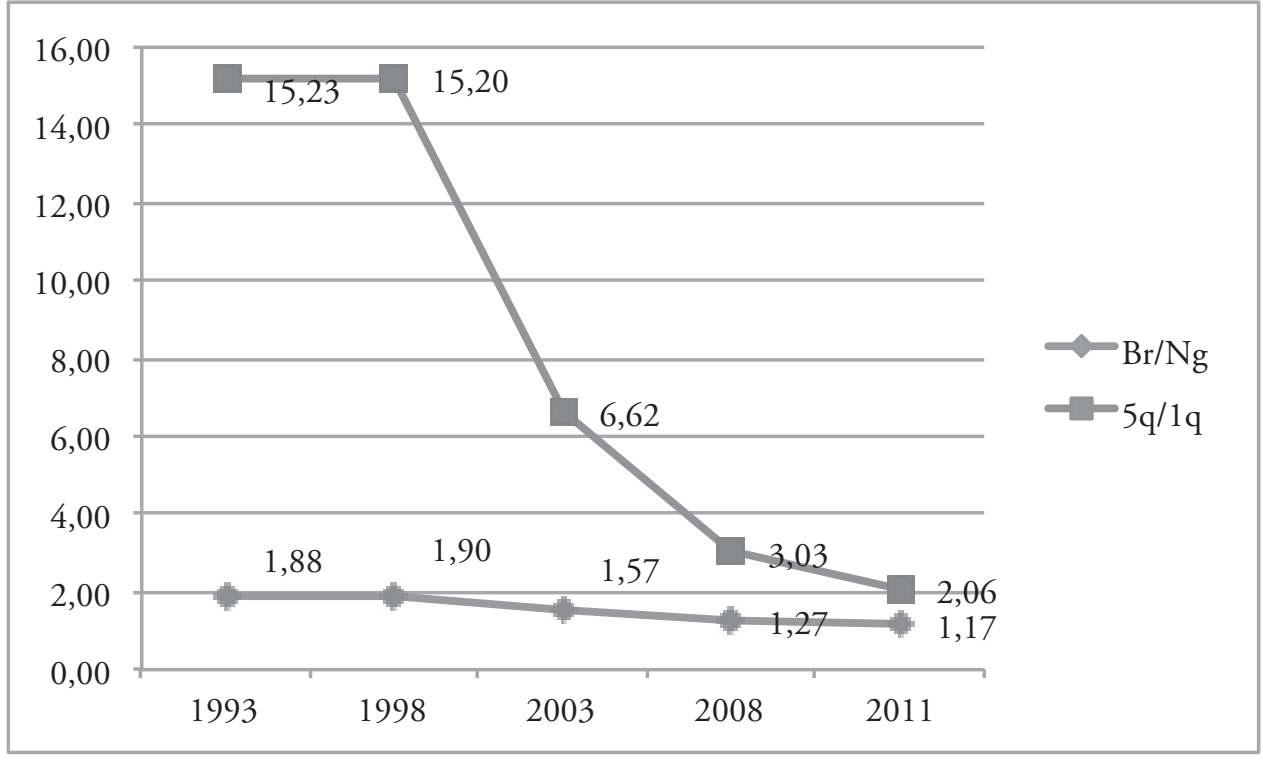

Fonte: PNAD/IBGE, tabulação própria.

Gráfico 6

Razão de Chances em Ter o Ensino Médio Completo dos Negros e Brancos dentro dos Quintis entre os Jovens de 18 a 29 anos

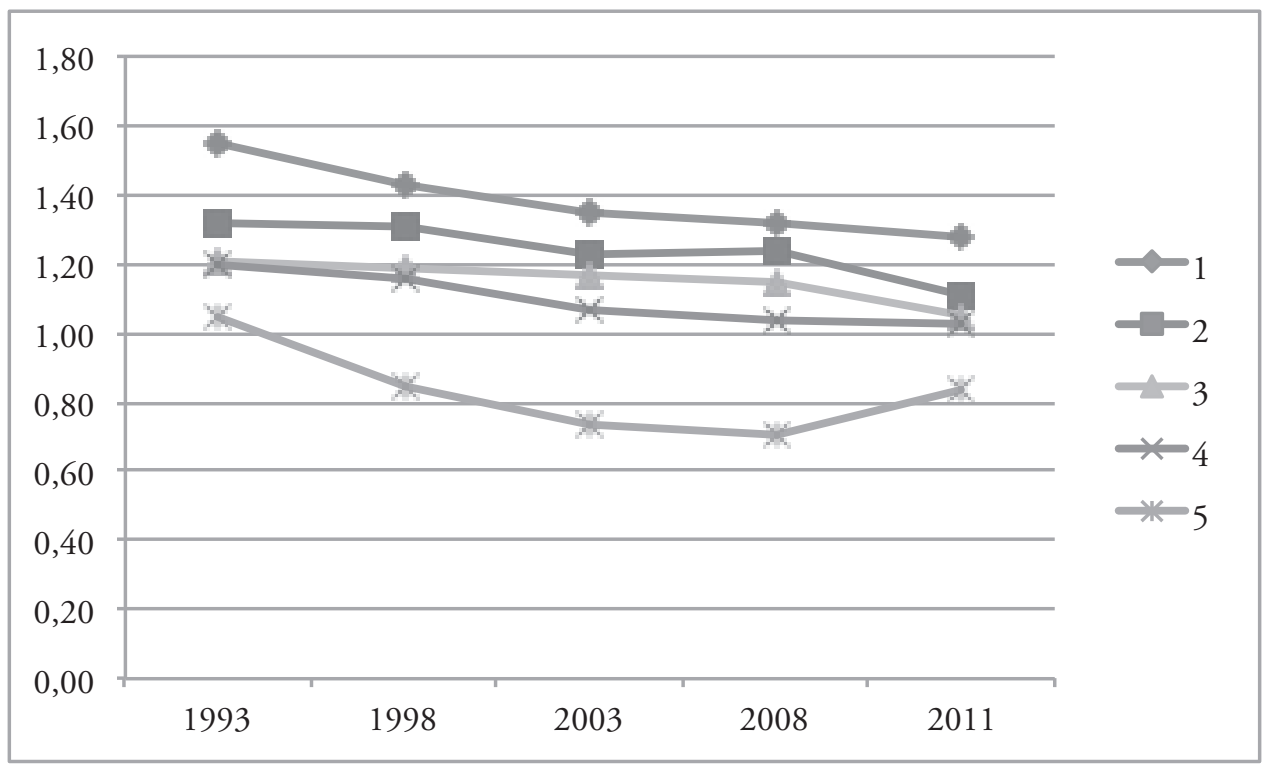

Fonte: PNAD/IBGE, tabulação própria. 
Um resultado do contexto de crise e desemprego, que levou muito jovens à procura de trabalho.

A recuperação econômica ampliou a geração de emprego e o percentual de jovens elegíveis que só trabalhava voltou a subir, passando de $54 \%$, em 2003, para 58,8\%, em 2011. Outras variações importantes foram entre aqueles que só procuraram trabalho, dos quais, mesmo mantendo percentual superior ao do início dos anos de 1990, observamos uma queda; e entre os jovens que nada declararam em relação a trabalho e estudo, que ampliaram seu percentual de $8,2 \%$, em 2008 , para $10,6 \%$, em 2011, uma variação que vem chamado atenção.

As mudanças e permanências indicam a existência de perfis de trajetória: se inserir no mercado de trabalho, o que os torna suscetíveis à dinâmica de geração ou retração de emprego; prolongar o investimento educacional conjugando com o trabalho; e nada fazer em relação a trabalho e estudo. A dedicação exclusiva ao estudo é para poucos.

Por cor, no cenário do início dos anos de 1990, negros e brancos se distinguiam pelas maiores chances de os primeiros estarem trabalhando e desempre- gados. No entanto, as maiores desigualdades medidas pelas chances relativas estavam entre aqueles que só estudavam ou conjugavam trabalho e estudo. Isso significa dizer que para aqueles jovens com ensino médio completo estudar é quase um privilégio, mais bem aproveitado pelos brancos (Gráficos 6 e 7).

As dinâmicas de aumento e redução de oportunidades ocupacionais apontadas anteriormente incidiram de forma semelhante entre brancos e negros: reduzem nos anos de 1998 e 2003 mas voltam a subir em 2003 e 2008, sem alcançar o mesmo patamar de 1993. As demais situaçóes tiveram também pequenas alterações em termos percentuais, visualizadas no Gráfico 6, que incidiram na redução das desigualdades entre brancos e negros em todas, com exceção daqueles que nada declararam em relação a trabalho e estudo, pois, enquanto os brancos ampliam de $8,4 \%$ para $10 \%$, os negros vão de $9,5 \%$ para $13,1 \%$.

Entre os quintis mais ricos e pobres, os dados ganham um tom mais alarmante. A grande diferença entre os mais pobres e os mais ricos está concentrada nos percentuais daqueles que conjugavam traba-

Gráfico 7

Jovens com Ensino médio Completo em Relação ao Trabalho e Estudo

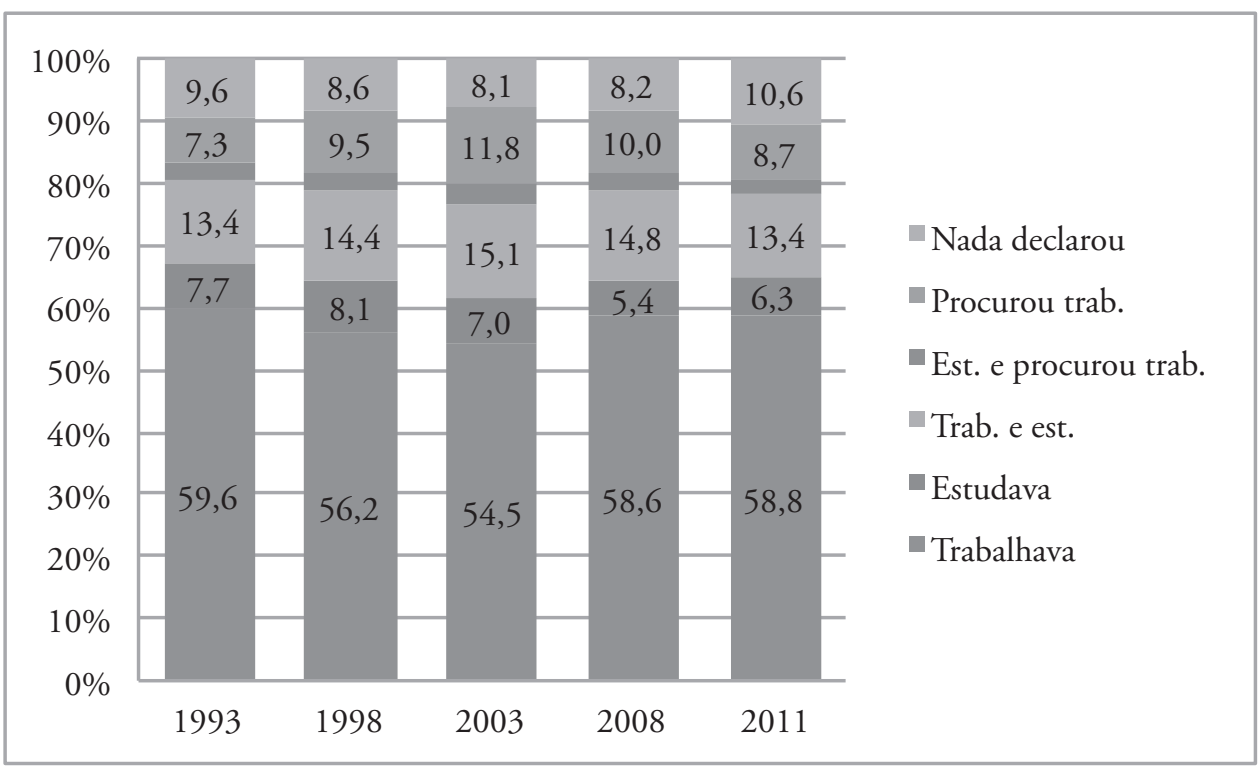

Fonte: PNAD/IBGE, tabulação própria. 


\section{Gráfico 8}

Jovens com Ensino Médio Completo por Cor em Relação ao Trabalho e Estudo

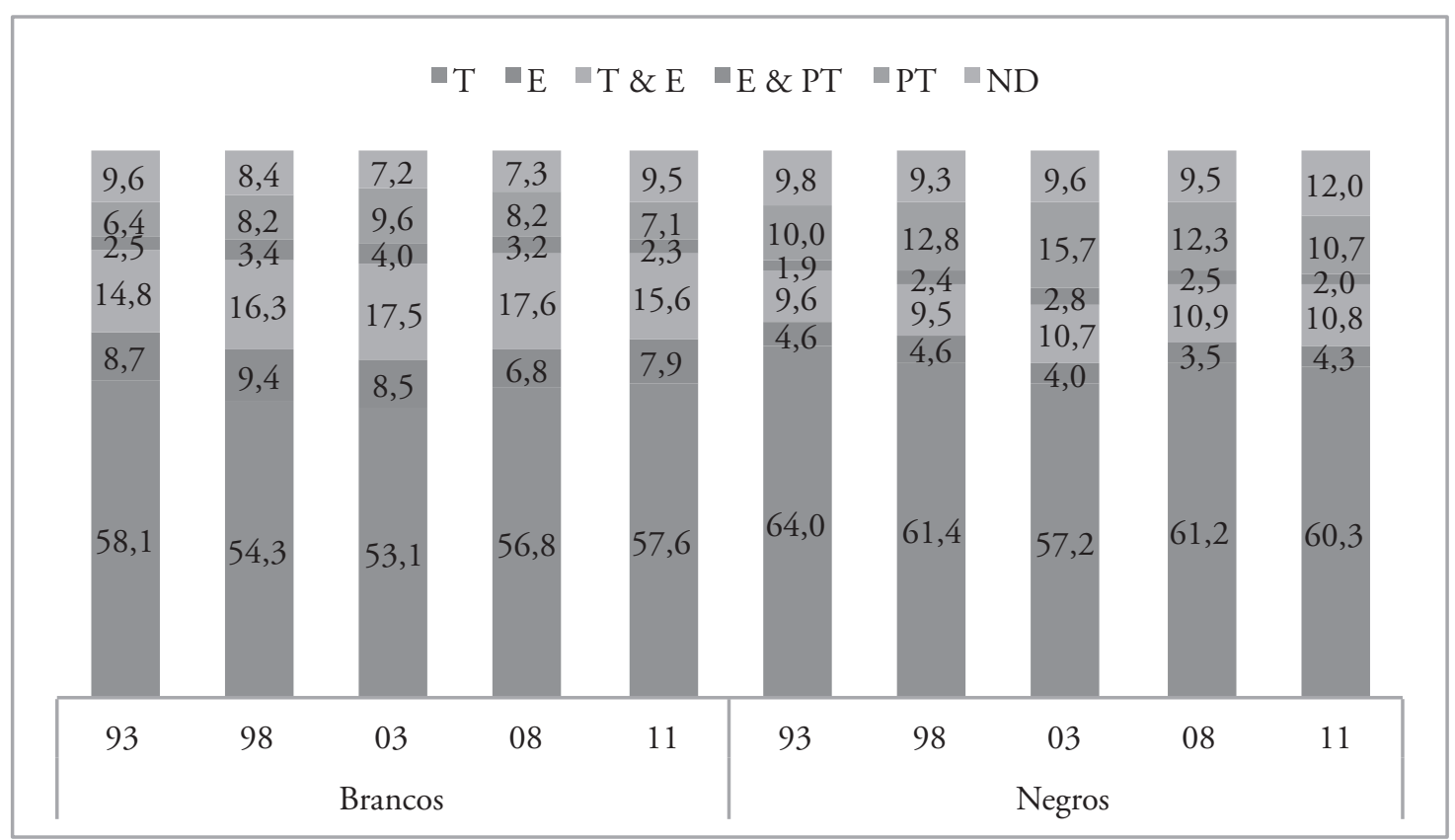

Fonte: PNAD/IBGE, tabulação própria.

\section{Gráfico 9}

Razão de Chances entre Jovens Brancos e Negros em Relação a Estudo e Trabalho

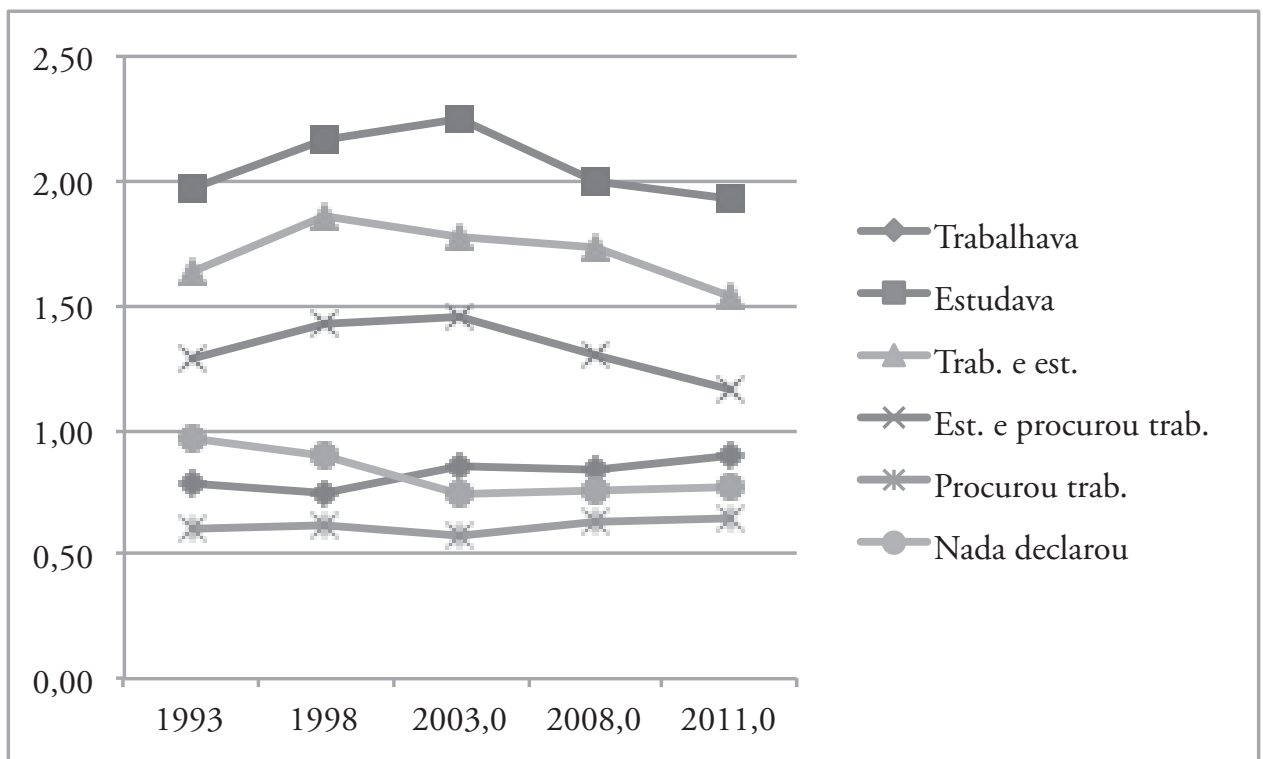

Fonte: PNAD/IBGE, tabulação própria. 
lho e estudo, procuravam trabalho e daqueles que nada declararam em relação a trabalho e estudo. Em $2011,2,8 \%$ dos mais pobres e $20,7 \%$ dos mais ricos trabalhavam e estudavam; $24,2 \%$ dos mais pobres e $3,2 \%$ dos mais ricos estavam procurando trabalho; e $27,5 \%$ dos mais pobres e $5,2 \%$ dos mais ricos nada declararam em relação a trabalho e estudo.

O que significa dizer que, para os mais pobres, sua situação só se altera se o contexto for favorável para sua incorporação no trabalho. Entre os mais ricos, embora o trabalho seja preponderante, a conjugação trabalho e estudo ganha muito mais espaço. Logo, se a reprodução do quadro dos mais ricos se manter parecida, sempre teremos um grupo apostando na educação, já entre os mais pobres a reprodução do quadro implica manterem-se bem distantes da aposta na educação.

Analisando pela disponibilidade de fazer apostas na continuidade do processo educacional, a renda sem dúvida pesa bastante para afastar os jovens de tudo, inclusive do trabalho. Quantos foram adiante, então?

No começo dos anos de 1990, 36,6\% tiveram acesso ao ensino superior; nos anos de 1998 e 2003, esse percentual diminui para $34 \%$ e volta a crescer para 37,4\%, em 2011. Aqueles que não estudavam somavam, em 1993, 59,1\% e, em 2011, passaram para $62 \%$. Há nesses dados um achado importante: não obstante a crescente oferta de vagas, do ponto de vista percentual o aumento dos jovens que fazem aposta no ensino superior é pouco expressivo.

Os estudos sobre os jovens de baixa renda no ensino médio e suas expectativas de vida nos fornecem elementos para dar conta de parte do que vem ocorrendo. Eles apontam que a maioria tem expectativas sobre futuro e projeto de vida difusos e poucas informaçōes sobre os mecanismos de acesso ao ensino superior. Heringer (2013) cita, por exemplo, no estudo de caso sobre uma escola em Cidade de Deus, ${ }^{2}$ que muitos alunos não tinham ouvido falar do Prouni e que pouca informação tinham sobre o Enem. Leão, Dayrell e Reis (2011) identificam gru-

Gráfico 10

Jovens com Ensino Médio Completo por Quintil de Renda em Relação ao Trabalho e Estudo

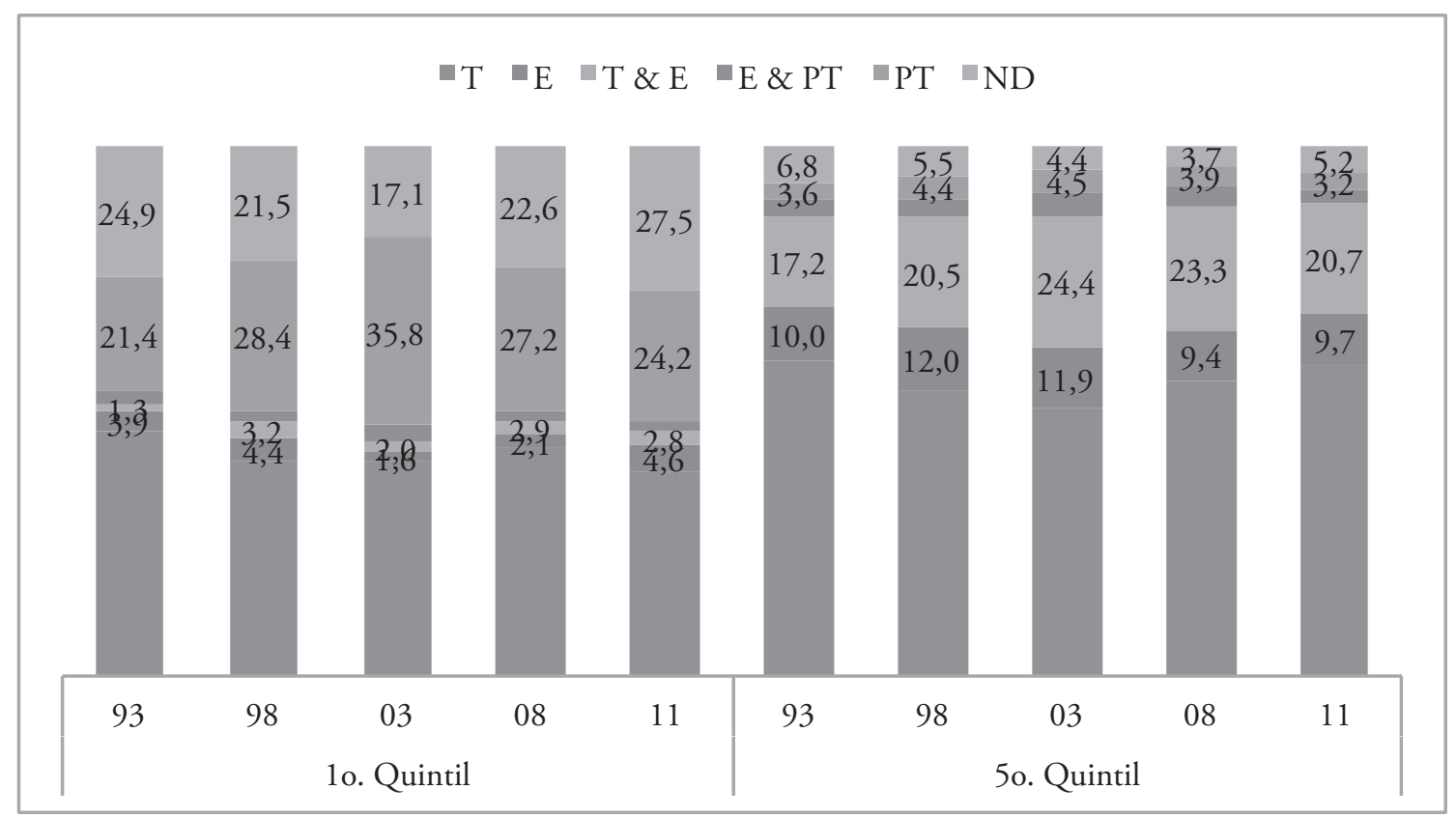

Fonte: PNAD/IBGE, tabulação própria. 
Gráfico 11

Jovens com Ensino Médio Completo por Cor em Relação ao Estudo

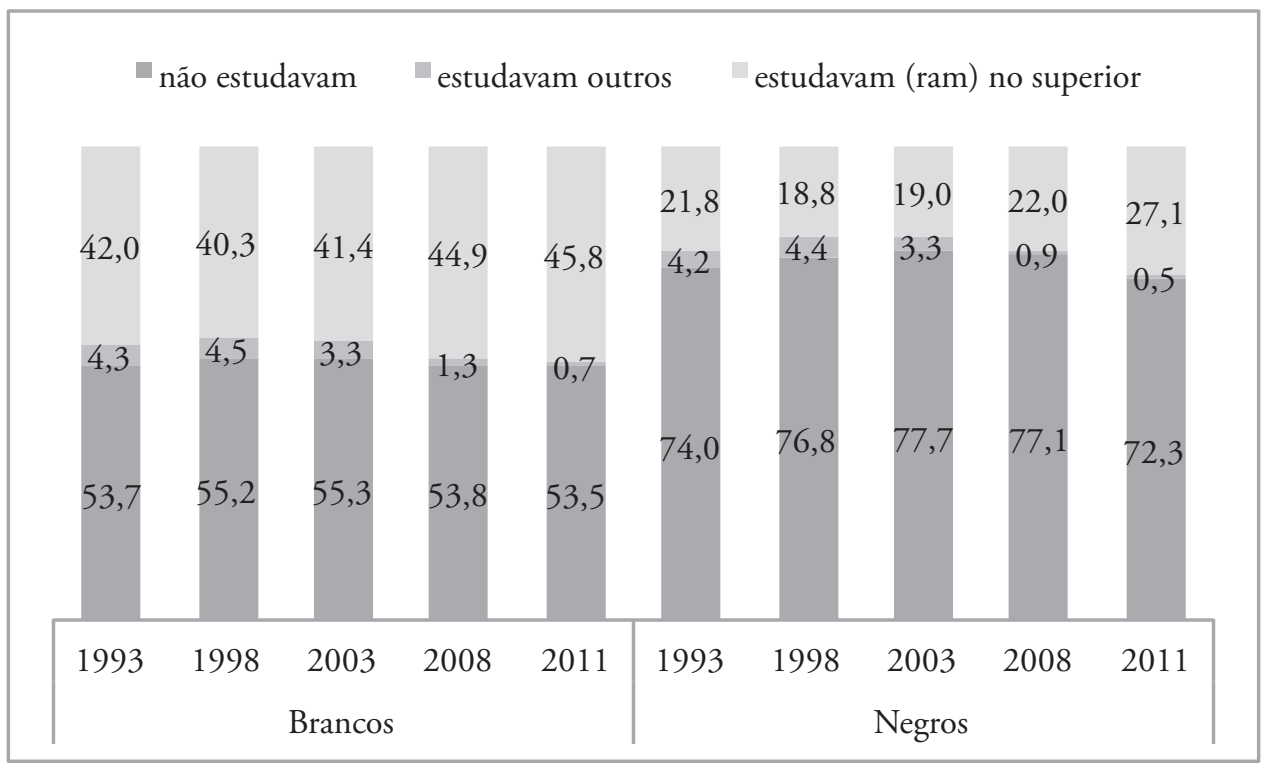

Fonte: PNAD/IBGE, tabulação própria.

pos que se dividem entre aqueles que têm como projeto a entrada imediata no ensino superior, em geral mais jovens e com adequação série-idade; aqueles que desejam fazer o ensino superior, mas primeiro investirão na estabilidade através de cursos técnicos e trabalho estável; os que afirmaram encerrar ensino médio para conseguir um trabalho melhor; e aqueles que não desejavam nada com muita clareza.

Desse modo, as escolas da baixa renda acomodam diferentes projetos e expectativas de vida. Bem diferente das escolas das classes médias e elite, cujos projetos são muito mais uniformes em direção ao ensino superior.

As diferenças entre brancos e negros é grande, como ilustra o Gráfico 9. Em 1993, 53,7\% dos jovens brancos e $74,5 \%$ dos jovens negros não estudam e $42 \%$ dos jovens brancos e $21,3 \%$ dos negros estão no ensino superior. Em 1998, jovens brancos e negros reduzem um pouco a aposta no ensino superior e, nos anos 2000, ampliam o ingresso, ultrapassando o patamar do começo da década anterior e alcançando, em 2011, 45,8\% dos brancos e
$27,1 \%$ dos negros - entre estes, um aumento proporcionalmente maior.

O Gráfico 11 apresenta apenas os percentuais dos jovens que tiveram acesso ao ensino superior e expõe as diferenças entre os quintis e suas oscilações ao longo do tempo.

Os jovens do primeiro e do segundo quintis de renda incorporam a população-alvo de muitos programas de reservas de vagas. Por isso, suas tendências são interessantes para a nossa discussão. Em 1993, 88\% dos jovens mais pobres não estudavam e $9 \%$ tiveram acesso ao ensino superior, percentuais que não se mantém porque, em 2003, aumenta o dos que não estudam $(91,9 \%)$ e reduz o dos que ingressaram no superior (5\%). Mas há uma recuperação em 2011, e o percentual de acesso ao ensino superior passa para $11,5 \%$.

Com indicadores muito parecidos, entre os jovens do segundo quintil, em 1993, 10,2\% tiveram acesso ao ensino superior; em 1998 e 2003, esse percentual cai, voltando a subir para 15,4\%, em 2011. O contexto de expansão do ensino superior impul- 
sionada pelo setor privado dos anos de 1990 e da primeira década de 2000 não favoreceu os jovens dos quintis mais baixos, afinal, o custo para estar na universidade privada ainda era alto. Melhores indicadores de acesso só aparecem no fim da década.

Os quintis de renda do meio e o mais alto estão em outro patamar de acesso ao ensino superior. Em 1993, os jovens do terceiro, quarto e quinto quintis tinham, respectivamente, $17,4 \%, 23,5 \% \mathrm{e}$ $50,7 \%$. Os jovens do terceiro e quarto quintis sofrem as mesmas oscilações apontadas: queda em 1998 para iniciar recuperação em 2003. Apenas os jovens no quintil mais alto não tiveram redução de percentual, pelo contrário, mesmo pequeno, o sentido sempre foi de crescimento. A manutenção do crescimento dos mais ricos é um indicador de que esse grupo ainda não alcançou um ponto de saturação: ainda há uma demanda em crescimento.

Com magnitudes bem diferentes, as tendências observadas construíram movimentos de aumentos e redução das desigualdades por cor e renda com diferenças e aproximações.
No momento em que houve redução no percentual dos jovens negros e brancos no acesso ao nível superior, aumentou a desigualdade de cor, pois a redução foi proporcionalmente maior para os negros. Mas o que observa a partir dos anos 2000 é a queda contínua da desigualdade, indicando que, como o avanço dos brancos não se dá na mesma intensidade, os negros jovens estão conseguindo, mesmo que com passos lentos, aproveitar o contexto de expansão. O menor ritmo dos brancos sugere que esse grupo pode estar perto da saturação e abrindo espaço para os negros (hipótese MMI).

Já em relação à renda, observamos que o crescimento contínuo entre os mais ricos e de oscilação entre os mais pobres redesenhou a desigualdade de acesso entre os dois, visível na comparação entre a razão de chances do primeiro e quinto quintis e segundo e quinto quintis no Gráfico 13. A desigualdade amplia e reduz a partir de 2003 e 2008, mas a queda foi insuficiente para garantir o patamar da década anterior.

Gráfico 12

Percentual do Acesso ao Ensino Superior no por Quintil de Renda

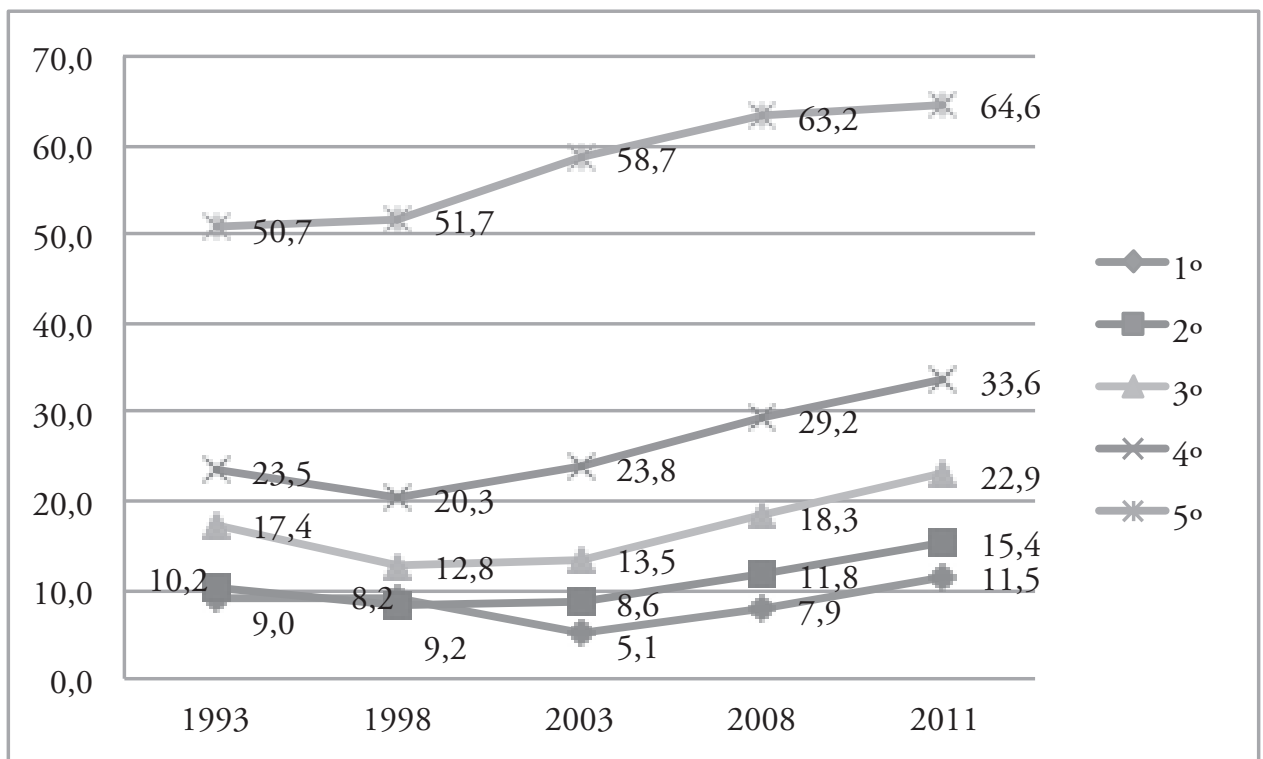

Fonte: PNAD/IBGE, tabulação própria. 
O fim da década de 2000, mesmo trazendo sinais de melhores desempenhos para todos os grupos em desvantagem de acesso, não implica uma queda brusca da desigualdade entre brancos e negros. Mais grave ainda: a despeito da ampliação do acesso dos mais pobres no ensino superior, a desigualdade entre ricos e pobres não alcança o patamar do contexto mais restritivo dos anos de 1990.

$\mathrm{E}$ a renda quando combinado com a cor, como fica? Como visto, os jovens do primeiro quintil têm uma queda no acesso ao ensino superior em 2003. A queda dos brancos foi um pouco maior - passou de $13,8 \%$, em 1993 , para $6,2 \%$, em 2003 , e os negros de $5,3 \%$ para $4,1 \%$-, reduzindo a desigualdades entre eles. A partir de 2008, o percentual de jovens no ensino superior volta a subir e, em 2011, chega a $17,3 \%$ entre os brancos e $8,5 \%$ entre os negros. Mas, como os brancos dão um salto proporcionalmente maior que os negros, a queda da desigualdade (Tabela 5) não se mantém, e negros e brancos ampliam sua distância novamente, porém sem restaurar os padrōes da década de 1990. Con- sequentemente, embora os negros pobres ampliem seu ingresso, são os brancos pobres que parecem aproveitar mais as novas oportunidades criadas. ${ }^{3}$

No segundo quintil, diferentemente do que ocorreu no primeiro, os negros experimentam uma estabilidade no percentual de jovens que tiveram acesso ao ensino superior. Ao longo de dez anos os percentuais ficaram em torno 5,6\%. A partir de 2008 há uma ampliação mais significativa, que chega em 2011 a 13,2\%. Os brancos, embora tivessem percentuais muito maiores de jovens no ensino superior, sofrem uma redução em 1998, que incide na redução da desigualdade entre brancos e negros. $\mathrm{O}$ crescimento proporcionalmente menor dos brancos a partir de 2003 e o salto dado pelos negros em 2008 resultou na redução da desigualdade entre brancos e negros, indicando que os negros aproveitaram mais as oportunidades.

Nos terceiro e quarto quintis o patamar de acesso ao nível superior aumenta, e as desigualdades entre negros e brancos são as menores. Em 1993, 20\% dos brancos e $12,5 \%$ dos negros do terceiro quintil

\section{Gráfico 13}

Razão de Chances de Estar no Ensino Superior

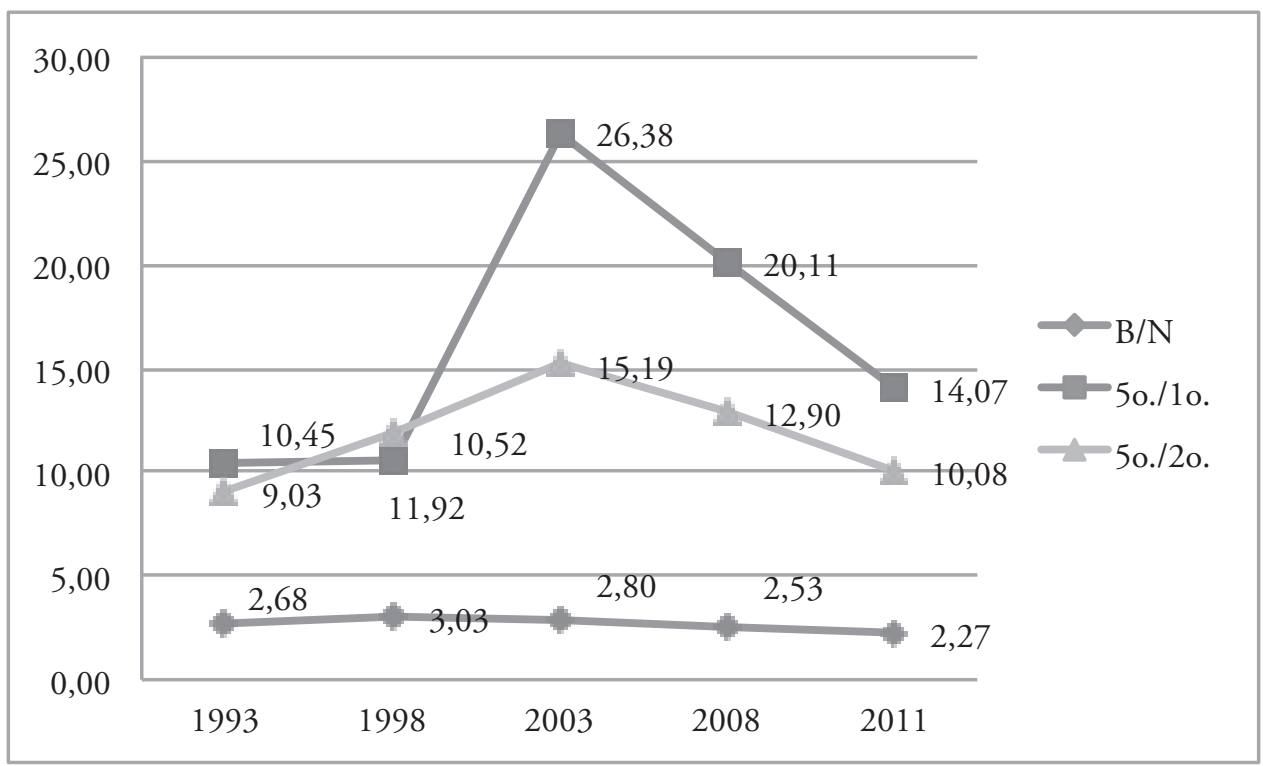

Fonte: PNAD/IBGE, tabulação própria. 
estavam no superior. Em 1998, os percentuais diminuem, mas voltam a crescer de 2003 e 2011, chegando a $26,4 \%$ dos brancos e a $19,7 \%$ dos negros. Os jovens negros e brancos do quarto quintil têm maiores percentuais - em 1993, tinham, respectivamente, $26,4 \%$ e $16,6 \%$ - e sofrem queda em 1998 , mas se recuperam em 2003, chegando a $37 \%$ e 29,4\% em 2011. Os aumentos e reduções ocorridos resultaram no aumento da desigualdade no fim dos anos de 1990 para iniciar a tendência de queda nos anos seguintes.

Os jovens que estão no quinto quintil são aqueles com mais chances de terem acesso ao ensino superior. Em 1993, 36,\% dos negros e 53,4\% dos brancos estavam lá. Ao longo do tempo, brancos e negros estabelecem tendências diferentes - os brancos engatam a ampliação contínua e os negros só pegam a onda em 2003. Consequentemente, cresce a desigualdade entre brancos e negros em 1998, se- guida de queda em 2003, estabilização em 2008 e pequeno aumento em 2011. Visto dessa forma, fica evidente que a expansão e diversificação dos anos 2000 afeta muito pouco a desigualdade racial na elite de renda.

O retrato do período analisado pode ser assim descrito (Gráfico 14). Os maiores percentuais estavam e continuam com os jovens brancos do quintil mais rico, seguido pelos jovens negros do mesmo quintil. Os negros do quarto quintil estavam abaixo dos brancos do terceiro, mas ao longo do tempo se aproximam, e os negros passam a ter uma pequena vantagem. Mesmo assim permanecem distantes dos brancos do quarto quintil. As linhas do gráfico que representam os demais grupos ficam entrelaçadas, e nisso o gráfico é proposital. É possível identificar que os negros do terceiro tinham um percentual pior que os brancos no segundo quintil. Ao longo do tempo, os brancos do primeiro se aproximam

\section{Gráfico 14}

Percentual de Jovens Brancos e Negros por Quintil com Acesso ao Ensino Superior

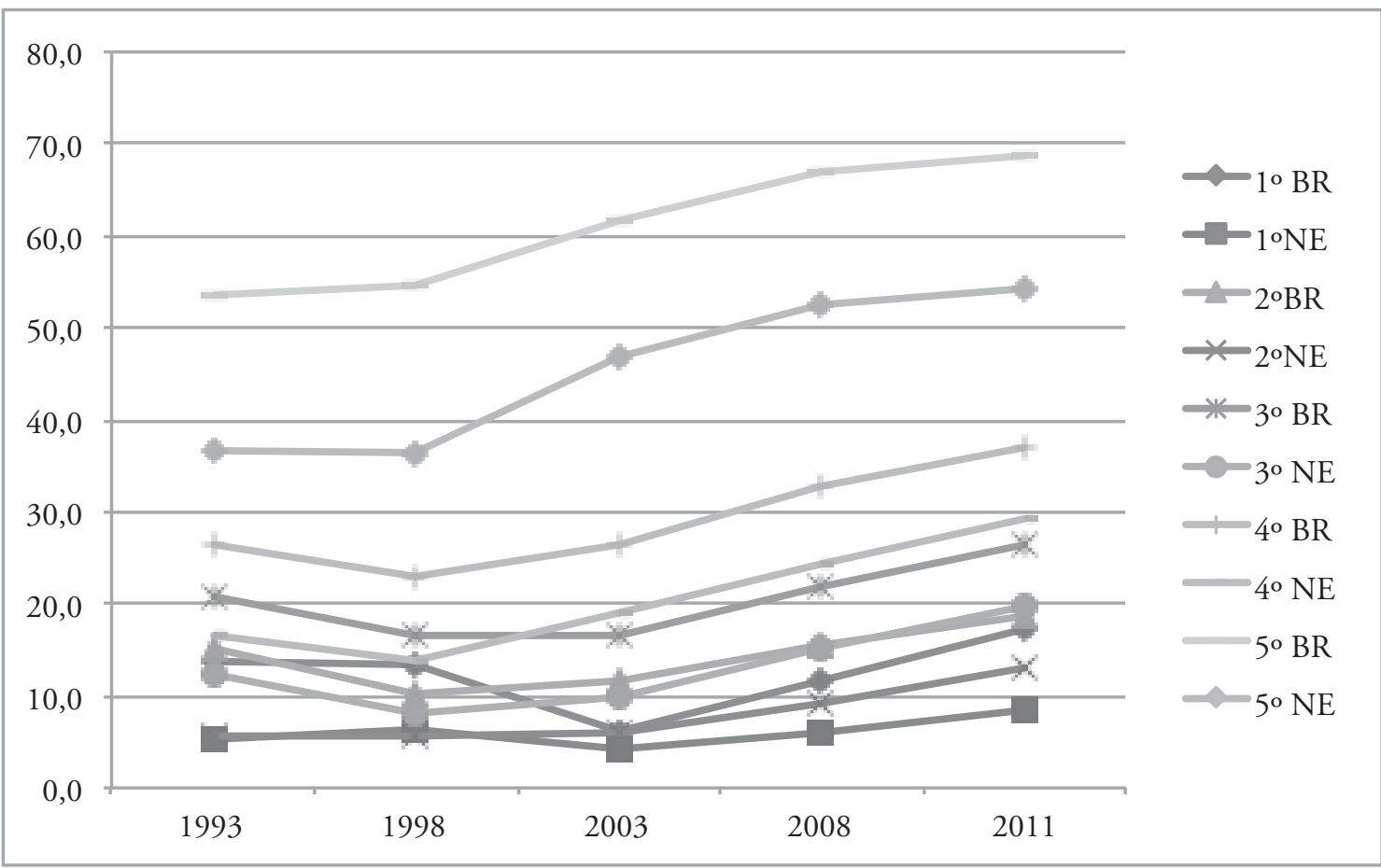

Fonte: PNAD/IBGE, tabulação própria. 
desses grupos. E, por fim, os negros do primeiro e segundo quintis, embora ampliem seu percentual, vão sendo deixados para trás.

Sem dúvida, a desigualdade no acesso ao ensino superior entre os jovens negros e brancos nos quintis está menor do que quando o acesso era mais restrito. No entanto, os polos de renda são os lugares onde os negros acompanham como menos velocidade o ritmo dos brancos. O cenário que se configura, então, é de uma elite e uma pobreza racialmente mais desigual no acesso ao ensino superior. Aqueles que conseguem ultrapassar as barreiras estão nos quintis intermediários de renda (Tabela 5). Diante desse cenário e agregando as análises de Carvalhaes, Feres Jr. e Daflon (2013) sobre os impactos da Lei de Cotas nos estados, nos quais se identifica maior competitividade entre os negros de baixa renda para a aquisição de vagas no ensino superior, o horizonte não parece muito promissor.

Tabela 5

Razão de Chances entre Brancos e Negros
dentro dos Quintis

\begin{tabular}{cccccc}
\hline & $\mathbf{1 9 9 3}$ & $\mathbf{1 9 9 8}$ & $\mathbf{2 0 0 3}$ & $\mathbf{2 0 0 8}$ & $\mathbf{2 0 1 1}$ \\
\hline $1 \mathrm{q}$ & 2,84 & 2,33 & 1,53 & 2,06 & 2,24 \\
\hline $2 \mathrm{q}$ & 3,02 & 1,95 & 2,10 & 1,80 & 1,49 \\
\hline $3 \mathrm{q}$ & 1,83 & 2,23 & 1,77 & 1,56 & 1,46 \\
\hline $4 \mathrm{q}$ & 1,80 & 1,86 & 1,53 & 1,52 & 1,41 \\
\hline $5 \mathrm{q}$ & 1,99 & 2,11 & 1,83 & 1,83 & 1,85 \\
\hline
\end{tabular}

Fonte: PNAD/IBGE, tabulação própria.

\section{Considerações finais}

Nos anos escolhidos para análise, o Brasil caminhou em duas direçôes: redução das desigualdades de renda e ampliação das oportunidades educacionais em todos os níveis. Isso permitiu o aumento do acesso e finalização do ensino médio para todos, em especial, ricos e pobres e negros e brancos, resultando na queda da desigualdade entre esses grupos. Não só a demanda por ensino superior foi ampliada, como também foi produzida uma diversificação socioeconômica.

A resposta veio, segundo o MEC, através da expansão e diversificação dos sistemas de ensino superior para atender clientela específicas com demandas de formação. A oferta de ensino superior sofreu algumas mudanças significativas que começaram com a expansão das vagas na rede privada em maior proporção, a diversificação dos cursos, o barateamento das mensalidades e a criação de programas públicos de incentivo ao preenchimento das vagas nessas unidades e acesso dos grupos sociais em desvantagens através de programas de reserva de vagas para alunos de escola pública, renda baixa e cor/raça.

Nesse contexto, como entender quem faz e quem não faz a aposta no ensino superior? Elegeram-se para tanto os jovens de 18 a 29 anos com ensino médio completo e analisamos seus destinos escolares (não estudar, estudar outro curso ou estar no ensino superior).

Inicialmente foram analisados os jovens de 18 a 29 anos que finalizaram o ensino médio. Observamos que esse grupo se aproxima da população acima de 18 anos em termos dos processos que experimentam: redução da desigualdade por raça e por renda, mas enquanto por raça estamos atingindo quase a igualdade, a renda ainda é um fator gerador de desigualdade; a desigualdade de raça entre os mais pobres e mais ricos é a maior de todas ao fim da década, mas a vantagem entre os mais ricos é dos negros, indicando a saturação dos brancos nesse grupo de renda.

Em seguida, as análises se concentraram naqueles jovens com o ensino médio completo - os elegíveis. A seleção do olhar para aqueles que finalizaram o ensino médio supõe que outras transiçōes tenham sido feitas e que a análise sobre elas fique de fora (Bourdieu e Passeron, 1974). Por outro lado, ela permite identificar elementos que podem ajudar a compreender aqueles que fazem apostas ou não mais robustas na escolarização no contexto de expansão do ensino superior e políticas de inclusão ampliadas.

Dentre os achados, destaca-se que existe uma parcela que se mantém fora da aposta no ensino superior a despeito de conjunturas mais ou menos favoráveis. O aumento entre 1993 e 2011 foi menor que $1 \%$. Dados que, vistos à luz dos estudos 
qualitativos sobre expectativas dos jovens do ensino médio, fazem bastante sentido: há falta de projetos e de informação de como chegar ao ensino superior, bem como outras expectativas de futuro que não incorporam essa aposta.

No entanto, analisando por grupos de cor e renda, os anos 2000 sinalizam para o maior acesso dos grupos em desvantagem, negros e mais pobres, o que não implica uma queda brusca da desigualdade em relação aos grupos em vantagem. A tendência é uma queda muito lenta das desigualdades.

Foi fundamental identificar que as oportunidades para avançar em direção à educação superior são mais desigualmente distribuídas entre brancos e negros quando estes estão nos polos de renda. A constatação por si só traz duas questôes. A primeira é a de que mesmo na pobreza a cor tem um efeito importante nos destinos escolares dos jovens. A segunda, de que a renda termina por não dar conta exclusivamente das desigualdades: a desigualdade no quintil mais rico é a segunda maior. A população negra acumula desvantagens com a discriminação racial resultando em menos recursos para competição mesmo estando no nível de renda mais alto.

O dado estimulante está na aproximação dos negros e brancos nos quintis de renda intermediários, indicando que os negros nessas faixas aproveitaram mais as oportunidades educacionais. É possível que nessa faixa a estratificação educacional seja transferida para os cursos; um estudo sobre essas escolhas pode favorecer melhor compreensão das formas estratificação do ensino superior.

A discussão aqui apresentada mostra que o Brasil ainda não resolveu o problema do acesso desigual ao ensino superior. Por isso, ainda temos muito o que dizer sobre a dimensão quantitativa e agregar junto a isso a dimensão qualitativa desse ingresso. $\mathrm{O}$ conjunto de estudos, incluindo o nosso, utilizando diferentes bases de dados e modelos estatísticos, mostraram a impossibilidade de assumir um único modelo ou corroborar hipóteses clássicas da literatura (Silva, 2003; Ribeiro, 2007; entre outros). Da mesma forma que, não obstante a rede de ensino pública permita maior chance de alcançar melhores ocupaçôes (Prates, Silva e Paula, 2012), seguir a rede de ensino privada ou pública não configura caminhos qualitativamente diferentes (Mont'Alvão, 2011).
Desse modo, no debate sobre as políticas de inclusão no ensino superior, entre a renda e raça, os sinais são de que é necessário reter os dois, mas não necessariamente atrelados, afinal, são mecanismos distintos de ação na produção de desigualdades sociais que conjugados as potencializam.

\section{Notas}

1 Segundo Sampaio (2011), o valor médio das mensalidades caiu de $\mathrm{R} \$$ 869, em 1996, para R\$ 467, em 2009. Nos cursos de administração, a média de mensalidades diminuiu de $\mathrm{R}$ \$ 532, em 1999, para R \$ 367, em 2009.

2 Segundo o Digest of Education Statistic (NCES, 2013), em 2011, dos jovens de 18 a 21 anos estavam inscritos no ensino superior: 50\% nos Estados Unidos; 21\% no México; 39\% no Chile; 15\% no Brasil.

3 Além dos autores mencionados, Silva, Souza e Roditi (1986), Hasenbalg e Silva (1999), Henriques (2001), Osório e Soares (2005), Osório (2009) e Marteleto, Carvalhaes e Hubert (2012) também apontam claramente para a persistência da raça nas transições e desigualdades educacionais.

4 As chances de ocorrência de um evento é a razão entre o sucesso e o fracasso (p/100-p). A razão de chances é uma forma de comparar as chances em dois grupos, sendo calculada pela razão entre a chance do grupo $1(\mathrm{p} / 1-\mathrm{p})$ e do grupo 2 (q/1-q). Quando a razão é igual a um, as chances são iguais; quando é superior a um, as chances do primeiro grupo são maiores; quando é inferior a um, as chances do segundo grupo são maiores. Assim, quanto mais próximo de um, mais chances de os dois grupos se aproximarem e menor a diferença entre eles.

5 Foi instituído pela Emenda Constitucional n. 14, de setembro de 1996, e regulamentado pela Lei n. 9424, de 24 de dezembro do mesmo ano, e pelo Decreto n. 2264, de junho de 1997. Foi implantado nacionalmente em $1^{\circ}$ de janeiro de 1998, quando passou a vigorar a nova sistemática de redistribuição dos recursos destinados ao ensino fundamental (MEC, 2014).

6 Criado pela Emenda Constitucional n. 53/2006 e regulamentado pela Lei n. $11494 / 2007$ e pelo Decreto n. $6253 / 2007$.

7 No questionário da PNAD, as perguntas sobre escolaridade englobam uma série de perguntas. Para todos indivíduos que declararam ter frequentado escola se pergunta o último curso e série que estava cursando e em que foi aprovado. Com base nessas duas variáveis, construímos a variável "nível de escolaridade". 
8 O gráfico deixa evidente que o valor numérico das razões de chances é bem distinto: enquanto a razão entre quintis está na dezena, a razão entre cor está na unidade. Estão postas no mesmo gráfico, contudo, porque correspondem à mesma unidade de mensuração.

9 O Uniafro foi criado em 2005 como um programa de açôes afirmativas para a população negra nas instituições públicas de educação superior. Surgiu de um acordo entre o MEC e os Núcleos de Estudos Afrobrasileiros (Neabs) e foi responsável pelo primeiro edital da bolsa de permanência na universidade, mas suas ações também vão em outras direções, como formação de professores.

10 Vale dizer que os dados para 18-24 e 18-29 são muito próximos, e as variaçōes, decimais.

11 Os dados do Censo da Educação Superior (MEC, 2013) são bem evidentes. Em 2011, nos cursos presenciais, 3.644.979 matrículas eram noturnas (63,5\%), 1.057.202 eram matutinas (18,4\%), 806.862 matrículas eram de turno integral (14,0\%) e 237.719 matrículas eram vespertinas $(4,1 \%)$. Só que as matrículas noturnas privadas somavam 3.037.399 e as municipais noturnas totalizam 91.557. Na categoria federal, 453.573 matrículas eram do turno integral, seguido por 275.762 do noturno. Na categoria estadual a distribuição está menos concentrada: 240.261 no noturno, 136.454 no matutino e 131.532 no integral.

12 A favela entrou em evidência pelo sucesso do romance de Paulo Lins, tornado filme por Fernando Meirelles.

13 Outros estudos que exploram a questão de gênero e cor descortinam o "núcleo duro" de resistência: as jovens negras mais pobres. Os dados ao longo do tempo sobre sua situação em relação a trabalho e estudo mostra um crescimento proporcionalmente maior daquelas que não declararam nada (as "nem, nem") (Picanço, 2012).

\section{BIBLIOGRAFIA}

ALVES, Fátima. (2010), "Escolhas familiares, estratificação educacional e desempenho escolar: quais as relaçôes”. Dados, 53 (2): 447-468.

ARUM, Richard; GAMORAN, Adam \& SHAVIT, Yossi. (2007), "More inclusion than diversion: expansion, differntiation and market structure in higher education", in Richard Arum, Adam Gamoran e Yossi Shavit (orgs.), Stratification in higher education, a comparative study, Stanford, Stanford University Press.
BARBOSA, Maria Ligia \& SANTOS, Clarissa. (2011), "A permeabilidade social nas carreiras do ensino superior". Cadernos do CRH, 24 (63): 535-554.

BOWLES, Samuel \& GINTIS, Herbert. (1976), Schooling in capitalist America. Nova York, Basic Books.

BREEN, Richard \& GOLDTHORPE, John. (1997), "Explaining educational differentials: towards a formal rational action theory". $R a$ tionality and Society, 9 (3): 275-305.

BREEN, Richard \& JONSSON, Jan. (2000) "Analyzing educational careers: a multinomial transition model". American Sociological Review, 65 (5): 754-772.

BOUDON, Raymond. (1981), Desigualdade de oportunidades. Brasília, Editora da UnB.

BOURDIEU, Pierre \& PASSERON, Jean-Claude. (1974), A reprodução: elementos para uma teoria do sistema de ensino. Rio de Janeiro, Francisco Alves.

CASTRO, Maria Helena. (1999), "As desigualdades regionais no sistema educacional brasileiro", in Ricardo Henriques (org.), Desigualdade e pobreza no Brasil, Rio de Janeiro, Ipea.

CARVALHES, Flavio; FERES JR., João \& DAFLON, Verônica. (2013), "O impacto da Lei de Cotas nos estados: um estudo preliminar". Textos para discussão Geema (Iesp-Uerj), n. 1, pp. $1-17$.

COLLINS, Randall. (1979), The credential society: an historical sociology of education and stratification. Nova York, Academic Press.

COMIM, Alvaro; BARBOSA, Jerônimo. (2011), "Trabalhar para estudar: sobre a pertinência da noção de transição escola-trabalho no Brasil". Novos Estudos - Cebrap, 91: 75-95

DAFLON, Verônica; FERES JR., João. \& CAMPOS, Luiz. (2013), "Ações afirmativas raciais no ensino superior público brasileiro: um panorama analítico". Cadernos de Pesquisa, 48 (148): 302-327.

FERNANDES, Daniele. (2005), “Estratificação educacional, origem socioeconômica e raça no Brasil: as barreiras da cor". Prêmio Ipea 40 Anos, Brasília, Ipea.

GERBER, Theodore \& HOUT, Michael. (1995), "Educational stratification in Russia during 
the Russian Period". American Journal of Socio$\log y$, 101: 611-660.

GOLDTHORPE, John. (1996), "Class analysis and the reorientation of class theory: the case of persisting differentials in educational attainment". The British Journal of Sociology, 47, (3): 481-505.

(2007), "Explaining educational differentials", On sociology, Stanford, Stanford University Press.

HASENBALG, Carlos \& SILVA, Nelson. (1999), "Educação e diferenças raciais na mobilidade ocupacional no Brasil”, in Carlos Hasenbalg, Nelson Silva e Márcia Lima (orgs.), Cor e estratificação social, Rio de Janeiro, Contracapa.

(2000), "Tendências da desigualdade educacional no Brasil". Dados, 43 (3): 423-445.

HAUSER, Robert \& FEATHERMAN, David. (1976), "Equality of schooling: trends and prospects”. Sociology of Education, 49 (2): 99-120.

HENRIQUES, Ricardo. (2001), "Desigualdade racial no Brasil: evolução das condições de vida na década de 90". Texto para discussão do Ipea, n. 807.

HERINGER, Rosana. (2013). Expectativas de acesso ao ensino superior: um estudo de caso na $\mathrm{Ci}$ dade de Deus, Rio de Janeiro. Rio de Janeiro, edição do autor.

. (2012), Censo da Educação Superior 2011. Disponível em portal.inep.gov.br/web/censo-da-educacao-superior, consultado em mar. 2014.

INEP. (2014), Censo da Educação Superior 2013. Disponível em portal.inep.gov.br/web/censo-da-educacao-superior, consultado em mar. 2014.

LEÃO, Geraldo; DAYRELL, Juarez \& REIS, Juliana. (2011). "Juventude, projetos de vida e ensino médio". Revista Educação \& Sociedade, 32 (117): 1067-1084.

LUCAS, Samuel. (2001), "Effectively maintained inequality: education transitions, track mobility, and social background effects". American Journal of Sociology, 106 (6): 1642-1490.

(2009), "Stratification theory, economic background, and educational attain- ment: a formal analysis". Rationality and Society, 21: 459-511.

MARTELETO, Letícia; CARVALHAES, Flavio \& HUBERT, Celia. (2012), "Desigualdades de oportunidades educacionais dos adolescentes no Brasil e no México". Revista Brasileira de Estudos Populacionais, 26 (2): 277-302.

MONT'ALVĀO, Arnaldo. (2011), "Estratificação educacional no Brasil no século XXI". Dados: Revista de Ciências Sociais, 54 (2): 389-430.

NCES - National Center of Education Statistic. (2013), Digest education statisc. Disponível em nces.ed.gov/programs/digest/d13/tables/ dt13_601.40.asp, consultado em mar. 2014.

NEVES, Clarissa. (2007), "Desafios da educação superior". Sociologias, 17: 14-21.

. (2012), "Ensino superior no Brasil: expansão, diversificação e inclusão". Trabalho apresentado no XXX International Congress of the Latin American Studies Association. São Francisco, CA, 30 maio-10 jun.

NEVES, Clarissa; MORCHE, Bruno \& ANHAIA, Bruna. (2011), "Educação superior no Brasil: acesso, equidade e políticas de inclusão social". ALAS: Controversias y Concurrências Latinoamericanas, 4: 123-140.

NOGUEIRA, Maria Alice. (1998). "A escolha do estabelecimento de ensino pelas famílias: a ação discreta da riqueza cultural". Revista Brasileira de Educação, 7: 42-56.

OSÓRIO, Rafael. (2009), "Classe, raça e acesso ao ensino superior no Brasil”. Cadernos de Pesquisa, 39: 867-880.

OSÓRIO, Rafael \& SOARES, Serguei. (2005), "A geração 80: um documentário estatístico sobre a produção das diferenças educacionais entre negros e brancos", in Sergei Soares et al. (orgs.), Os mecanismos de discriminação racial nas escolas brasileiras, Rio de Janeiro, Ipea.

PARSONS, Talcott. (1970), "Equality and inequality in modern society, or social stratification revised", in Edward Laumann (org.), Social stratification: research and theory for the 1970s. Indianapolis, Bobbs-Merril.

PICANÇO, Felícia. (2012), "Quem vai e quem fica: apostas no ensino superior". Trabalho apresentado no $36^{\circ}$ encontro Anual da Anpocs, out. 2012.

PRATES, Antonio. (2007), "Universidades vs. terciarização do ensino superior: a lógica da expansão do acesso com manutenção da desigualdade - caso brasileiro". Sociologias, 17: 102 -123. 
PRATES, Antonio; SILVA, Matheus \& PAULA, Túlio de. (2012), "Natureza administrativa das instituições de ensino superior, gestão organizacional e o acesso aos postos de trabalho de maior prestígio no mercado de trabalho". Sociedade e Estado, 27 (1): 25-44.

QUEIROZ, Delcele \& SANTOS, Jocélio. (2007), "Sistema de cotas: um multiculturalismo brasileiro”. Ciência e Cultura, 59: 41-45.

RAFTERY, Adrian \& HOUT, Michael. (1993), "Maximally maintained inequality: expansion, reform, and opportunity in irish education". Sociology of Education, 66 (1): 41-62.

RIBEIRO, Carlos Antônio. (2007), Estrutura de classe e mobilidade social no Brasil. Bauru, SP, Edusc.

(2011), "Desigualdade de oportunidades e resultados educacionais no Brasil". Dados, 54: 41-88.

SANTOS, Hélio; SOUZA, Marcilene Garcia de \& SASAKI, Karen. (2013), "O subproduto social advindo das cotas raciais na educação superior do Brasil'. Revista Brasileira de Estudos Pedagógicos, 94 (237): 542-563.

SAMPAIO, Helena. (2011), "O setor privado de ensino superior no Brasil: continuidades e transformaçôes". Revista Ensino Superior Unicamp, 4: 28-43.

SILVA, Nelson. (2003), "Expansão escolar e estratificação racial no Brasil”, in Carlos Hasenbalg e Nelson Silva (orgs), Origens e destinos: desigualdades sociais ao longo da vida, Rio de Janeiro, Topbooks.

SILVA, Nelson; SOUZA, Alberto \& RODITI, Déborah. (1985), "Industrialização e desigualdades educacionais no Brasil”. Relatório de Pesquisa e Desenvolvimento 002/85. Rio de Janeiro, Laboratório Nacional de Computação Científica.

TREIMAN, D. (1970), "Industrialization and social stratification", in Edward Laumann (org.), Social stratification: research and theory for the 1970s, Indianapolis, Bobbs Merrill. 


\section{ANEXO}

Tabela A

População acima de 18 Anos segundo Nível de Escolaridade

\begin{tabular}{lrrrrrrrrr}
\hline \multirow{2}{*}{$\begin{array}{c}\text { Nível de } \\
\text { escolaridade }\end{array}$} & \multicolumn{4}{c}{ Anos } & \multicolumn{3}{c}{ Ampliação/redução } \\
\cline { 2 - 10 } & $\mathbf{1 9 9 3}$ & $\mathbf{1 9 9 8}$ & $\mathbf{2 0 0 3}$ & $\mathbf{2 0 0 8}$ & $\mathbf{2 0 1 1}$ & $\mathbf{9 3 / 9 8}$ & $\mathbf{9 8 / 0 3}$ & $\mathbf{0 3 / 0 8}$ & $\mathbf{0 8 / 1 1}$ \\
\hline - 1 ano & 18,9 & 16,1 & 13,5 & 11,8 & 13,2 & $-14,7$ & $-16,2$ & $-12,5$ & 12,3 \\
\hline Prim. incompleto & 17,8 & 15,7 & 12,8 & 10,3 & 8,2 & $-12,0$ & $-18,7$ & $-19,2$ & $-20,5$ \\
\hline Prim. Completo & 16,6 & 14,7 & 12,8 & 11,0 & 9,6 & $-11,4$ & $-12,9$ & $-13,8$ & $-12,6$ \\
\hline EF incompleto & 15,1 & 15,5 & 14,5 & 12,3 & 10,9 & 3,3 & $-6,8$ & $-14,9$ & $-11,9$ \\
\hline EF completo & 8,2 & 9,2 & 9,3 & 9,6 & 10,1 & 11,8 & 1,2 & 2,8 & 5,5 \\
\hline EM incompleto & 4,5 & 5,5 & 6,1 & 6,5 & 6,0 & 21,5 & 11,3 & 6,8 & $-8,4$ \\
\hline EM completo & 10,9 & 13,9 & 19,6 & 24,2 & 26,3 & 26,8 & 41,3 & 23,3 & 8,6 \\
\hline Sup inc/com & 7,7 & 9,0 & 10,8 & 13,9 & 15,5 & 16,2 & 20,7 & 27,7 & 11,9 \\
\hline S/inf & 0,3 & 0,4 & 0,6 & 0,4 & 0,2 & 67,3 & 35,8 & $-33,1$ & $-43,6$ \\
\hline Total & 100,0 & 100,0 & 100,0 & 100,0 & 100,0 & & & & \\
\hline
\end{tabular}

Fonte: Elaboração própria a partir de dados PNAD/IBGE.

Tabela B

População Branca acima de 18 Anos segundo Nível de Escolaridade

\begin{tabular}{lrrrrrrrrr}
\hline \multirow{2}{*}{$\begin{array}{c}\text { Nível de } \\
\text { escolaridade }\end{array}$} & \multicolumn{4}{c}{ Anos } & \multicolumn{4}{c}{ Ampliação/redução } \\
\cline { 2 - 10 } & $\mathbf{1 9 9 3}$ & $\mathbf{1 9 9 8}$ & $\mathbf{2 0 0 3}$ & $\mathbf{2 0 0 8}$ & $\mathbf{2 0 1 1}$ & $\mathbf{9 3 / 9 8}$ & $\mathbf{9 8 / 0 3}$ & $\mathbf{0 3 / 0 8}$ & $\mathbf{0 8 / 1 1}$ \\
\hline - 1 ano & 12,4 & 10,5 & 8,9 & 8,1 & 9,2 & $-15,2$ & $-15,4$ & $-9,1$ & 13,5 \\
\hline Prim. incompleto & 15,5 & 13,2 & 10,6 & 8,5 & 6,8 & $-14,7$ & $-20,1$ & $-19,6$ & $-19,6$ \\
\hline Prim. Completo & 18,0 & 15,4 & 13,1 & 11,1 & 10,0 & $-14,4$ & $-14,9$ & $-15,4$ & $-9,7$ \\
\hline EF incompleto & 15,2 & 15,1 & 13,1 & 10,6 & 9,4 & $-0,7$ & $-13,5$ & $-18,9$ & $-11,0$ \\
\hline EF completo & 9,2 & 9,9 & 9,8 & 9,4 & 9,8 & 8,5 & $-1,5$ & $-4,0$ & 4,4 \\
\hline EM incompleto & 5,0 & 5,8 & 5,9 & 5,8 & 5,2 & 14,8 & 1,8 & $-0,5$ & $-11,1$ \\
\hline EM completo & 13,2 & 16,5 & 22,3 & 26,2 & 27,8 & 24,3 & 35,2 & 17,8 & 6,1 \\
\hline Sup inc/com & 11,2 & 13,1 & 15,9 & 19,9 & 21,6 & 17,0 & 21,1 & 25,3 & 8,2 \\
\hline S/inf & 0,2 & 0,5 & 0,5 & 0,4 & 0,2 & 89,1 & 17,8 & $-34,1$ & $-50,3$ \\
\hline Total & 100,0 & 100,0 & 100,0 & 100,0 & 100,0 & & & &
\end{tabular}

Fonte: Elaboração própria a partir de dados PNAD/IBGE. 
Tabela C

População Negra acima de 18 Anos segundo Nível de Escolaridade

\begin{tabular}{lrrrrrrrrr}
\hline \multirow{2}{*}{$\begin{array}{c}\text { Nível de } \\
\text { escolaridade }\end{array}$} & \multicolumn{4}{c}{ Anos } & \multicolumn{4}{c}{ Ampliação/redução } \\
\cline { 2 - 10 } & $\mathbf{1 9 9 3}$ & $\mathbf{1 9 9 8}$ & $\mathbf{2 0 0 3}$ & $\mathbf{2 0 0 8}$ & $\mathbf{2 0 1 1}$ & $\mathbf{9 3 / 9 8}$ & $\mathbf{9 8 / 0 3}$ & $\mathbf{0 3 / 0 8}$ & $\mathbf{0 8 / 1 1}$ \\
\hline - 1 ano & 27,6 & 23,6 & 19,0 & 15,5 & 17,3 & $-14,5$ & $-19,3$ & $-18,5$ & 11,2 \\
\hline Prim. incompleto & 21,0 & 19,1 & 15,4 & 12,2 & 9,6 & $-9,5$ & $-19,0$ & $-20,8$ & $-21,7$ \\
\hline Prim. Completo & 14,6 & 13,7 & 12,4 & 10,9 & 9,2 & $-6,4$ & $-9,6$ & $-11,7$ & $-15,4$ \\
\hline EF incompleto & 15,0 & 16,3 & 16,3 & 14,2 & 12,3 & 8,4 & 0,1 & $-12,8$ & $-13,2$ \\
\hline EF completo & 7,0 & 8,2 & 8,7 & 9,8 & 10,4 & 17,7 & 6,2 & 11,8 & 6,5 \\
\hline EM incompleto & 3,9 & 5,2 & 6,4 & 7,3 & 6,8 & 33,8 & 24,4 & 13,2 & $-6,9$ \\
\hline EM completo & 7,8 & 10,4 & 16,4 & 22,2 & 24,8 & 33,1 & 58,0 & 34,9 & 11,9 \\
\hline Sup inc/com & 2,8 & 3,2 & 4,6 & 7,5 & 9,4 & 14,1 & 44,5 & 62,4 & 25,0 \\
\hline S/inf & 0,3 & 0,4 & 0,7 & 0,4 & 0,3 & 44,5 & 61,7 & $-33,1$ & $-39,5$ \\
\hline Total & 100,0 & 100,0 & 100,0 & 100,0 & 100,0 & & & & \\
\hline
\end{tabular}

Fonte: Elaboração própria a partir de dados PNAD/IBGE.

Tabela D

População do $1^{\circ}$ Quintil de Renda (Mais Pobres) acima de 18 Anos segundo Nível de Escolaridade

\begin{tabular}{lrrrrrrrrrr}
\hline \multirow{2}{*}{$\begin{array}{l}\text { Nível de } \\
\text { escolaridade }\end{array}$} & \multicolumn{1}{l}{ Anos } & \multicolumn{7}{c}{ Ampliaçáo/reduçáo } \\
\cline { 2 - 11 } & $\mathbf{1 9 9 3}$ & $\mathbf{1 9 9 8}$ & $\mathbf{2 0 0 3}$ & $\mathbf{2 0 0 8}$ & $\mathbf{2 0 1 1}$ & $\mathbf{9 3 / 9 8}$ & $\mathbf{9 8 / 0 3}$ & $\mathbf{0 3 / 0 8}$ & $\mathbf{0 8 / 1 1}$ \\
\hline - 1 ano & 38,1 & 33,9 & 24,7 & 20,0 & 22,7 & $-11,1$ & $-27,1$ & $-19,0$ & 13,2 \\
\hline Prim. incompleto & 27,6 & 26,0 & 22,2 & 18,3 & 13,4 & $-5,9$ & $-14,6$ & $-17,6$ & $-26,5$ \\
\hline Prim. Completo & 15,0 & 15,6 & 15,1 & 13,6 & 11,2 & 4,3 & $-3,3$ & $-9,9$ & $-17,8$ \\
\hline EF incompleto & 11,8 & 14,4 & 18,4 & 18,9 & 16,5 & 22,5 & 27,9 & 2,8 & $-12,8$ \\
\hline EF completo & 3,4 & 4,4 & 7,4 & 9,3 & 10,9 & 30,2 & 67,9 & 25,4 & 16,7 \\
\hline EM incompleto & 1,7 & 2,5 & 4,8 & 7,0 & 7,8 & 43,4 & 93,9 & 45,7 & 10,0 \\
\hline EM completo & 2,0 & 2,6 & 6,3 & 11,1 & 15,1 & 29,8 & 146,3 & 75,4 & 36,4 \\
\hline Sup inc/com & 0,3 & 0,4 & 0,4 & 1,3 & 2,1 & 9,6 & 3,0 & 238,6 & 68,0 \\
\hline S/inf & 0,1 & 0,3 & 0,7 & 0,5 & 0,4 & 145,2 & 122,2 & $-28,1$ & $-24,7$ \\
\hline Total & 100,0 & 100,0 & 100,0 & 100,0 & 100,0 & & & & \\
\hline
\end{tabular}

Fonte: Elaboração própria a partir de dados PNAD/IBGE. 
Tabela E

População do $5^{\circ}$ Quintil (Mais Rico) acima de 18 Anos segundo Nível de Escolaridade

\begin{tabular}{lrrrrrrrrr}
\hline \multirow{2}{*}{$\begin{array}{c}\text { Nível de } \\
\text { escolaridade }\end{array}$} & \multicolumn{4}{c}{ Anos } & \multicolumn{5}{c}{ Ampliação/redução } \\
\cline { 2 - 11 } & $\mathbf{1 9 9 3}$ & $\mathbf{1 9 9 8}$ & $\mathbf{2 0 0 3}$ & $\mathbf{2 0 0 8}$ & $\mathbf{2 0 1 1}$ & $\mathbf{9 3 / 9 8}$ & $\mathbf{9 8 / 0 3}$ & $\mathbf{0 3 / 0 8}$ & $\mathbf{0 8 / 1 1}$ \\
\hline - 1 ano & 4,4 & 3,1 & 3,2 & 3,2 & 3,9 & $-30,6$ & 3,2 & 0,9 & 20,1 \\
\hline Prim. incompleto & 8,2 & 5,7 & 5,0 & 4,3 & 3,4 & $-30,6$ & $-12,0$ & $-13,1$ & $-21,9$ \\
\hline Prim. Completo & 13,4 & 10,3 & 9,0 & 7,8 & 6,7 & $-23,3$ & $-12,3$ & $-13,8$ & $-13,1$ \\
\hline EF incompleto & 11,1 & 9,0 & 7,4 & 6,0 & 5,4 & $-18,5$ & $-18,4$ & $-18,1$ & $-11,1$ \\
\hline EF completo & 10,1 & 9,7 & 7,7 & 7,0 & 7,1 & $-3,4$ & $-21,3$ & $-8,3$ & 1,3 \\
\hline EM incompleto & 5,8 & 6,3 & 4,5 & 4,4 & 3,5 & 9,5 & $-29,1$ & $-1,9$ & $-19,0$ \\
\hline EM completo & 22,1 & 26,1 & 29,1 & 29,3 & 29,7 & 18,4 & 11,3 & 0,8 & 1,5 \\
\hline Sup inc/com & 24,8 & 29,4 & 33,9 & 37,8 & 40,2 & 18,9 & 15,1 & 11,4 & 6,4 \\
\hline S/inf & 0,3 & 0,3 & 0,4 & 0,2 & 0,1 & 31,9 & 6,0 & $-48,5$ & $-65,0$ \\
\hline Total & 100,0 & 100,0 & 100,0 & 100,0 & 100,0 & & & &
\end{tabular}

Fonte: Elaboração própria a partir de dados PNAD/IBGE.

Tabela F

População Branca no $1^{\circ}$ Quintil de Renda acima de 18 Anos segundo Nível de Escolaridade

\begin{tabular}{lrrrrrrrrrr}
\hline \multirow{2}{*}{$\begin{array}{c}\text { Nível de } \\
\text { escolaridade }\end{array}$} & \multicolumn{4}{c}{ Anos } & \multicolumn{4}{c}{ Ampliação/reduçáo } \\
\cline { 2 - 11 } & $\mathbf{1 9 9 3}$ & $\mathbf{1 9 9 8}$ & $\mathbf{2 0 0 3}$ & $\mathbf{2 0 0 8}$ & $\mathbf{2 0 1 1}$ & $\mathbf{9 3 / 9 8}$ & $\mathbf{9 8 / 0 3}$ & $\mathbf{0 3 / 0 8}$ & $\mathbf{0 8 / 1 1}$ \\
\hline - 1 ano & 29,1 & 26,0 & 18,9 & 16,0 & 18,4 & $-10,8$ & $-27,1$ & $-15,3$ & 14,5 \\
\hline Prim. incompleto & 27,3 & 24,9 & 20,9 & 16,8 & 12,4 & $-8,7$ & $-16,1$ & $-19,4$ & $-26,3$ \\
\hline Prim. Completo & 19,3 & 19,4 & 17,7 & 14,8 & 12,6 & 0,7 & $-8,7$ & $-16,3$ & $-14,8$ \\
\hline EF incompleto & 14,6 & 17,0 & 19,7 & 19,4 & 16,3 & 16,7 & 15,7 & $-1,3$ & $-15,9$ \\
\hline EF completo & 4,2 & 5,4 & 8,6 & 10,3 & 11,6 & 27,6 & 58,4 & 20,5 & 12,5 \\
\hline EM incompleto & 2,0 & 2,9 & 5,0 & 7,3 & 7,8 & 45,2 & 74,9 & 45,4 & 8,1 \\
\hline EM completo & 2,8 & 3,2 & 7,8 & 12,8 & 17,3 & 12,4 & 144,4 & 64,8 & 35,1 \\
\hline Sup inc/com & 0,6 & 0,8 & 0,7 & 2,0 & 3,1 & 38,4 & $-19,5$ & 200,2 & 56,0 \\
\hline S/inf & 0,1 & 0,4 & 0,7 & 0,5 & 0,4 & 478,7 & 87,8 & $-36,1$ & $-19,0$ \\
\hline Total & 100,0 & 100,0 & 100,0 & 100,0 & 100,0 & & & & \\
\hline
\end{tabular}

Fonte: Elaboração própria a partir de dados PNAD/IBGE. 
Tabela G

População Negra no $1^{\circ}$ Quintil de Renda acima de 18 Anos segundo Nível de Escolaridade

\begin{tabular}{lrrrrrrrrr}
\hline \multirow{2}{*}{$\begin{array}{c}\text { Nível de } \\
\text { escolaridade }\end{array}$} & \multicolumn{4}{c}{ Anos } & \multicolumn{4}{c}{ Ampliação/redução } \\
\cline { 2 - 10 } & $\mathbf{1 9 9 3}$ & $\mathbf{1 9 9 8}$ & $\mathbf{2 0 0 3}$ & $\mathbf{2 0 0 8}$ & $\mathbf{2 0 1 1}$ & $\mathbf{9 3 / 9 8}$ & $\mathbf{9 8 / 0 3}$ & $\mathbf{0 3 / 0 8}$ & $\mathbf{0 8 / 1 1}$ \\
\hline - 1 ano & 42,3 & 37,6 & 27,2 & 21,5 & 24,3 & $-11,1$ & $-27,6$ & $-21,1$ & 13,2 \\
\hline Prim. incompleto & 27,7 & 26,4 & 22,7 & 18,9 & 13,9 & $-4,6$ & $-14,1$ & $-16,9$ & $-26,7$ \\
\hline Prim. Completo & 13,0 & 13,9 & 14,0 & 13,2 & 10,7 & 7,0 & 1,0 & $-6,1$ & $-19,1$ \\
\hline EF incompleto & 10,5 & 13,2 & 17,8 & 18,8 & 16,6 & 25,7 & 35,5 & 5,6 & $-11,9$ \\
\hline EF completo & 3,0 & 4,0 & 6,9 & 8,9 & 10,6 & 32,2 & 74,7 & 28,3 & 19,2 \\
\hline EM incompleto & 1,6 & 2,3 & 4,8 & 7,0 & 7,7 & 41,2 & 105,4 & 46,0 & 10,9 \\
\hline EM completo & 1,6 & 2,3 & 5,7 & 10,3 & 14,2 & 43,6 & 150,4 & 82,7 & 37,5 \\
\hline Sup inc/com & 0,2 & 0,2 & 0,2 & 1,0 & 1,8 & $-27,6$ & 58,0 & 303,1 & 76,4 \\
\hline S/inf & 0,1 & 0,2 & 0,6 & 0,5 & 0,3 & 67,6 & 153,2 & $-23,6$ & $-28,5$ \\
\hline Total & 100,0 & 100,0 & 100,0 & 100,0 & 100,0 & & & & \\
\hline
\end{tabular}

Fonte: Elaboração própria a partir de dados PNAD/IBGE.

Tabela $\mathbf{H}$

População Branca no 2o Quintil de Renda acima de 18 Anos segundo Nível de Escolaridade

\begin{tabular}{lccccccccc}
\hline \multirow{2}{*}{$\begin{array}{c}\text { Nível de } \\
\text { escolaridade }\end{array}$} & $\mathbf{9}$ & $\mathbf{3}$ Anos & \multicolumn{3}{c}{ Ampliação/reduçáo } \\
\cline { 2 - 10 } & $\mathbf{1 9 9 3}$ & $\mathbf{1 9 9 8}$ & $\mathbf{2 0 0 3}$ & $\mathbf{2 0 0 8}$ & $\mathbf{2 0 1 1}$ & $\mathbf{9 3 / 9 8}$ & $\mathbf{9 8 / 0 3}$ & $\mathbf{0 3 / 0 8}$ & $\mathbf{0 8 / 1 1}$ \\
\hline - 1 ano & 20,26 & 18,25 & 14,58 & 13,49 & 14,97 & $-9,9$ & $-20,1$ & $-7,5$ & 11,0 \\
\hline Prim. incompleto & 22,85 & 19,96 & 15,79 & 12,20 & 9,80 & $-12,6$ & $-20,9$ & $-22,7$ & $-19,7$ \\
\hline Prim. Completo & 22,01 & 19,38 & 15,98 & 13,34 & 11,61 & $-12,0$ & $-17,5$ & $-16,5$ & $-13,0$ \\
\hline EF incompleto & 17,96 & 20,55 & 19,69 & 16,61 & 14,16 & 14,4 & $-4,2$ & $-15,6$ & $-14,8$ \\
\hline EF completo & 6,90 & 8,78 & 11,46 & 11,72 & 12,27 & 27,3 & 30,6 & 2,2 & 4,7 \\
\hline EM incompleto & 3,54 & 4,70 & 7,06 & 8,03 & 7,26 & 32,6 & 50,3 & 13,7 & $-9,5$ \\
\hline EM completo & 5,06 & 6,63 & 13,26 & 20,37 & 24,92 & 31,0 & 99,8 & 53,6 & 22,4 \\
\hline Sup inc/com & 1,12 & 1,22 & 1,57 & 3,68 & 4,71 & 8,8 & 29,0 & 133,8 & 28,2 \\
\hline S/inf & 0,28 & 0,52 & 0,60 & 0,57 & 0,30 & 84,9 & 15,0 & $-5,1$ & $-47,0$ \\
\hline Total & 100,0 & 100,0 & 100,0 & 100,0 & 100,0 & & & & \\
\hline
\end{tabular}

Fonte: Elaboração própria a partir de dados PNAD/IBGE. 
Tabela I

População Negra no $2^{\circ}$ Quintil de Renda acima de 18 Anos segundo Nível de Escolaridade

\begin{tabular}{|c|c|c|c|c|c|c|c|c|c|}
\hline \multirow{2}{*}{$\begin{array}{c}\text { Nível de } \\
\text { escolaridade }\end{array}$} & \multicolumn{5}{|c|}{ Anos } & \multicolumn{4}{|c|}{ Ampliação/redução } \\
\hline & 1993 & 1998 & 2003 & 2008 & 2011 & 93/98 & $98 / 03$ & 03/08 & $08 / 11$ \\
\hline-1 ano & 31,2 & 27,8 & 21,7 & 18,0 & 20,5 & $-10,9$ & $-21,8$ & $-17,2$ & 13,8 \\
\hline Prim. incompleto & 23,7 & 21,9 & 17,2 & 13,7 & 10,7 & $-7,3$ & $-21,8$ & $-20,4$ & $-22,0$ \\
\hline Prim. Completo & 15,7 & 14,8 & 13,6 & 11,7 & 9,4 & $-5,3$ & $-8,7$ & $-13,4$ & $-19,6$ \\
\hline EF incompleto & 16,0 & 18,0 & 19,2 & 17,0 & 14,6 & 12,8 & 6,8 & $-11,6$ & $-13,9$ \\
\hline EF completo & 5,8 & 6,9 & 8,6 & 10,6 & 11,2 & 19,9 & 24,3 & 22,4 & 5,7 \\
\hline EM incompleto & 3,0 & 4,1 & 6,9 & 8,3 & 8,3 & 34,5 & 68,6 & 20,6 & $-0,5$ \\
\hline EM completo & 4,0 & 5,6 & 11,3 & 18,0 & 21,8 & 38,0 & 103,5 & 58,9 & 21,5 \\
\hline Sup inc/com & 0,4 & 0,5 & 0,8 & 2,3 & 3,2 & 20,1 & 71,2 & 181,2 & 40,5 \\
\hline S/inf & 0,3 & 0,4 & 0,7 & 0,5 & 0,3 & 33,8 & 84,9 & $-28,7$ & $-34,3$ \\
\hline Total & 100,0 & 100,0 & 100,0 & 100,0 & 100,0 & & & & \\
\hline
\end{tabular}

Fonte: Elaboração própria a partir de dados PNAD/IBGE.

Tabela J

População Branca no $3^{\circ}$ Quintil de Renda acima de 18 Anos segundo Nível de Escolaridade

\begin{tabular}{llllllllll}
\hline \multirow{2}{*}{$\begin{array}{c}\text { Nível de } \\
\text { escolaridade }\end{array}$} & \multicolumn{3}{c}{ Anos } & \multicolumn{3}{c}{ Ampliação/redução } \\
\cline { 2 - 11 } & $\mathbf{1 9 9 3}$ & $\mathbf{1 9 9 8}$ & $\mathbf{2 0 0 3}$ & $\mathbf{2 0 0 8}$ & $\mathbf{2 0 1 1}$ & $\mathbf{9 3 / 9 8}$ & $\mathbf{9 8 / 0 3}$ & $\mathbf{0 3 / 0 8}$ & $\mathbf{0 8 / 1 1}$ \\
\hline - 1 ano & 15,3 & 15,8 & 14,4 & 13,9 & 14,5 & 3,0 & $-8,4$ & $-3,8$ & 4,3 \\
\hline Prim. incompleto & 19,3 & 17,8 & 13,8 & 11,8 & 9,7 & $-8,0$ & $-22,1$ & $-14,5$ & $-17,6$ \\
\hline Prim. Completo & 21,5 & 18,1 & 15,3 & 13,0 & 12,0 & $-15,9$ & $-15,2$ & $-15,0$ & $-8,2$ \\
\hline EF incompleto & 18,9 & 19,2 & 16,3 & 13,2 & 11,6 & 1,8 & $-15,4$ & $-18,6$ & $-12,5$ \\
\hline EF completo & 9,1 & 10,4 & 11,0 & 11,1 & 11,2 & 13,3 & 6,1 & 0,8 & 1,1 \\
\hline EM incompleto & 5,3 & 5,7 & 7,2 & 7,0 & 6,0 & 7,4 & 26,9 & $-1,9$ & $-14,7$ \\
\hline EM completo & 8,2 & 10,4 & 17,8 & 23,9 & 27,0 & 26,9 & 70,7 & 34,4 & 12,9 \\
\hline Sup inc/com & 2,2 & 2,2 & 3,4 & 5,5 & 7,8 & 2,4 & 53,6 & 61,1 & 41,9 \\
\hline S/inf & 0,2 & 0,5 & 0,8 & 0,5 & 0,2 & 125,7 & 45,5 & $-38,8$ & $-56,0$ \\
\hline Total & 100,0 & 100,0 & 100,0 & 100,0 & 100,0 & & & &
\end{tabular}

Fonte: Elaboração própria a partir de dados PNAD/IBGE. 
Tabela K

População Negra no $3^{\circ}$ Quintil de Renda acima de 18 Anos segundo Nível de Escolaridade

\begin{tabular}{|c|c|c|c|c|c|c|c|c|c|}
\hline \multirow{2}{*}{$\begin{array}{c}\text { Nível de } \\
\text { escolaridade }\end{array}$} & \multicolumn{5}{|c|}{ Anos } & \multicolumn{4}{|c|}{ Ampliação/redução } \\
\hline & 1993 & 1998 & 2003 & 2008 & 2011 & $93 / 98$ & $98 / 03$ & 03/08 & $08 / 11$ \\
\hline-1 ano & 25,0 & 24,4 & 22,6 & 19,4 & 21,1 & $-2,5$ & $-7,6$ & $-14,0$ & 8,9 \\
\hline Prim. incompleto & 19,9 & 18,5 & 14,5 & 12,5 & 10,3 & $-6,9$ & $-21,6$ & $-13,9$ & $-17,4$ \\
\hline Prim. Completo & 15,6 & 14,0 & 12,1 & 10,8 & 9,7 & $-10,0$ & $-13,3$ & $-10,9$ & $-9,9$ \\
\hline EF incompleto & 18,4 & 17,6 & 16,0 & 13,8 & 11,8 & $-4,3$ & $-9,1$ & $-13,9$ & $-14,1$ \\
\hline EF completo & 8,2 & 8,6 & 9,3 & 9,8 & 10,5 & 4,6 & 8,0 & 4,9 & 7,1 \\
\hline EM incompleto & 4,2 & 5,8 & 6,8 & 7,3 & 6,5 & 38,0 & 18,5 & 6,6 & $-10,7$ \\
\hline EM completo & 7,2 & 9,4 & 16,2 & 22,2 & 24,6 & 31,8 & 71,2 & 37,6 & 10,8 \\
\hline Sup inc/com & 1,2 & 1,2 & 1,8 & 3,9 & 5,2 & $-0,1$ & 53,9 & 109,6 & 34,2 \\
\hline S/inf & 0,3 & 0,4 & 0,7 & 0,4 & 0,2 & 31,3 & 47,8 & $-40,9$ & $-43,4$ \\
\hline Total & 100,0 & 100,0 & 100,0 & 100,0 & 100,0 & & & & \\
\hline
\end{tabular}

Fonte: Elaboração própria a partir de dados PNAD/IBGE.

Tabela L

População Branca no $4^{\circ}$ Quintil de Renda acima de 18 Anos segundo Nível de Escolaridade

\begin{tabular}{|c|c|c|c|c|c|c|c|c|c|}
\hline \multirow{2}{*}{$\begin{array}{c}\text { Nível de } \\
\text { escolaridade }\end{array}$} & \multicolumn{5}{|c|}{ Anos } & \multicolumn{4}{|c|}{ Ampliação/redução } \\
\hline & 1993 & 1998 & 2003 & 2008 & 2011 & 93/98 & $98 / 03$ & 03/08 & $08 / 11$ \\
\hline-1 ano & 12,0 & 8,1 & 7,2 & 7,0 & 7,8 & $-32,4$ & $-11,5$ & $-1,7$ & 10,2 \\
\hline Prim. incompleto & 15,7 & 13,4 & 10,8 & 8,6 & 6,9 & $-14,7$ & $-19,6$ & $-20,3$ & $-20,1$ \\
\hline Prim. Completo & 19,4 & 17,0 & 14,6 & 12,7 & 11,7 & $-12,1$ & $-14,3$ & $-13,2$ & $-7,5$ \\
\hline EF incompleto & 17,2 & 17,0 & 13,6 & 10,8 & 9,9 & $-1,0$ & $-20,3$ & $-20,6$ & $-7,9$ \\
\hline EF completo & 10,9 & 12,4 & 11,7 & 11,0 & 11,2 & 14,0 & $-5,9$ & $-6,1$ & 2,7 \\
\hline EM incompleto & 5,9 & 7,1 & 6,7 & 6,3 & 5,6 & 20,1 & $-5,3$ & $-6,0$ & $-12,0$ \\
\hline EM completo & 13,3 & 18,2 & 26,7 & 31,7 & 32,4 & 37,1 & 46,6 & 18,6 & 2,2 \\
\hline Sup inc/com & 5,4 & 6,2 & 8,2 & 11,6 & 14,4 & 13,7 & 33,2 & 41,2 & 24,2 \\
\hline S/inf & 0,3 & 0,6 & 0,6 & 0,4 & 0,2 & 115,9 & 3,0 & $-30,9$ & $-53,0$ \\
\hline Total & 100,0 & 100,0 & 100,0 & 100,0 & 100,0 & & & & \\
\hline
\end{tabular}

Fonte: Elaboração própria a partir de dados PNAD/IBGE. 
Tabela M

População Negra no 40 Quintil de Renda acima de 18 Anos segundo Nível de Escolaridade

\begin{tabular}{|c|c|c|c|c|c|c|c|c|c|}
\hline \multirow{2}{*}{$\begin{array}{c}\text { Nível de } \\
\text { escolaridade }\end{array}$} & \multicolumn{5}{|c|}{ Anos } & \multicolumn{4}{|c|}{ Ampliação/redução } \\
\hline & 1993 & 1998 & 2003 & 2008 & 2011 & 93/98 & $98 / 03$ & 03/08 & $08 / 11$ \\
\hline-1 ano & 20,5 & 11,7 & 11,6 & 11,1 & 12,2 & $-42,8$ & $-1,1$ & $-3,9$ & 10,0 \\
\hline Prim. incompleto & 17,0 & 14,5 & 12,1 & 9,5 & 7,9 & $-15,1$ & $-16,0$ & $-21,5$ & $-16,7$ \\
\hline Prim. Completo & 15,2 & 13,8 & 11,9 & 10,6 & 9,4 & $-9,0$ & $-13,6$ & $-11,4$ & $-10,7$ \\
\hline EF incompleto & 16,8 & 18,1 & 14,7 & 12,2 & 10,6 & 7,5 & $-18,7$ & $-17,2$ & $-13,3$ \\
\hline EF completo & 9,8 & 12,3 & 10,3 & 10,4 & 10,6 & 25,9 & $-16,5$ & 1,2 & 2,2 \\
\hline EM incompleto & 5,4 & 7,7 & 7,6 & 7,4 & 6,2 & 40,6 & $-1,3$ & $-1,7$ & $-16,2$ \\
\hline EM completo & 11,9 & 17,8 & 25,5 & 29,9 & 31,5 & 49,8 & 43,3 & 17,3 & 5,3 \\
\hline Sup inc/com & 3,0 & 3,6 & 5,5 & 8,3 & 11,2 & 18,1 & 55,0 & 49,5 & 34,6 \\
\hline S/inf & 0,3 & 0,5 & 0,7 & 0,5 & 0,3 & 72,2 & 30,2 & $-27,4$ & $-47,2$ \\
\hline Total & 100,0 & 100,0 & 100,0 & 100,0 & 100,0 & & & & \\
\hline
\end{tabular}

Fonte: Elaboração própria a partir de dados PNAD/IBGE.

Tabela N

População Branca no $5^{\circ}$ Quintil de Renda acima de 18 Anos segundo Nível de Escolaridade

\begin{tabular}{|c|c|c|c|c|c|c|c|c|c|}
\hline \multirow{2}{*}{$\begin{array}{c}\text { Nível de } \\
\text { escolaridade }\end{array}$} & \multicolumn{5}{|c|}{ Anos } & \multicolumn{4}{|c|}{ Ampliação/redução } \\
\hline & 1993 & 1998 & 2003 & 2008 & 2011 & 93/98 & $98 / 03$ & 03/08 & $08 / 11$ \\
\hline-1 ano & 3,6 & 2,4 & 2,6 & 2,5 & 3,1 & $-31,7$ & 5,4 & $-4,8$ & 25,2 \\
\hline Prim. incompleto & 7,4 & 5,1 & 4,5 & 3,9 & 3,1 & $-30,4$ & $-11,8$ & $-13,2$ & $-21,1$ \\
\hline Prim. Completo & 13,3 & 10,2 & 9,1 & 7,7 & 6,9 & $-23,1$ & $-11,3$ & $-15,2$ & $-10,4$ \\
\hline EF incompleto & 10,6 & 8,4 & 6,7 & 5,6 & 4,8 & $-20,9$ & $-19,8$ & $-17,2$ & $-13,8$ \\
\hline EF completo & 10,0 & 9,4 & 7,4 & 6,5 & 6,8 & $-5,6$ & $-20,9$ & $-12,1$ & 3,5 \\
\hline EM incompleto & 5,5 & 6,0 & 4,1 & 3,9 & 3,3 & 8,1 & $-31,2$ & $-4,9$ & $-16,6$ \\
\hline EM completo & 22,1 & 26,0 & 28,5 & 28,2 & 28,4 & 17,4 & 9,5 & $-0,8$ & 0,5 \\
\hline Sup inc/com & 27,3 & 32,2 & 36,8 & 41,6 & 43,7 & 17,8 & 14,4 & 12,9 & 5,2 \\
\hline S/inf & 0,2 & 0,3 & 0,3 & 0,1 & 0,0 & 32,2 & 4,6 & $-53,0$ & $-67,8$ \\
\hline Total & 100,0 & 100,0 & 100,0 & 100,0 & 100,0 & & & & \\
\hline
\end{tabular}

Fonte: Elaboração própria a partir de dados PNAD/IBGE. 
Tabela $\mathbf{O}$

População Negra no $5^{\circ}$ Quintil de Renda acima de 18 Anos segundo Nível de Escolaridade

\begin{tabular}{llllllllll}
\hline \multirow{2}{*}{$\begin{array}{c}\text { Nível de } \\
\text { escolaridade }\end{array}$} & $\mathbf{4}$ & \multicolumn{3}{c}{ Anos } & \multicolumn{5}{c}{ Ampliação/redução } \\
\cline { 2 - 10 } & $\mathbf{1 9 9 3}$ & $\mathbf{1 9 9 8}$ & $\mathbf{2 0 0 3}$ & $\mathbf{2 0 0 8}$ & $\mathbf{2 0 1 1}$ & $\mathbf{9 3 / 9 8}$ & $\mathbf{9 8 / 0 3}$ & $\mathbf{0 3 / 0 8}$ & $\mathbf{0 8 / 1 1}$ \\
\hline - 1 ano & 7,5 & 5,5 & 5,3 & 5,1 & 5,6 & $-27,1$ & $-3,2$ & $-4,3$ & 11,8 \\
\hline Prim. incompleto & 11,1 & 7,7 & 6,7 & 5,3 & 4,1 & $-30,2$ & $-13,5$ & $-20,2$ & $-23,2$ \\
\hline Prim. Completo & 13,6 & 10,3 & 8,8 & 7,9 & 6,4 & $-24,5$ & $-14,3$ & $-10,4$ & $-18,1$ \\
\hline EF incompleto & 13,3 & 11,9 & 9,8 & 7,3 & 6,7 & $-10,5$ & $-18,3$ & $-24,8$ & $-8,8$ \\
\hline EF completo & 10,7 & 11,1 & 8,5 & 8,4 & 8,0 & 3,9 & $-23,6$ & $-1,7$ & $-4,9$ \\
\hline EM incompleto & 6,6 & 7,7 & 5,6 & 5,6 & 4,2 & 16,3 & $-26,8$ & $-0,7$ & $-24,3$ \\
\hline EM completo & 22,1 & 27,1 & 31,3 & 32,2 & 33,1 & 22,7 & 15,4 & 3,0 & 2,7 \\
\hline Sup inc/com & 14,7 & 18,2 & 23,5 & 27,9 & 31,7 & 23,7 & 29,5 & 18,7 & 13,7 \\
\hline S/inf & 0,4 & 0,5 & 0,5 & 0,3 & 0,1 & 30,0 & 6,0 & $-45,7$ & $-62,9$ \\
\hline Total & 100,0 & 100,0 & 100,0 & 100,0 & 100,0 & & & & \\
\hline
\end{tabular}

Fonte: Elaboração própria a partir de dados PNAD/IBGE. 



\section{JUVENTUDE POR COR E RENDA NO ACESSO AO ENSINO SUPERIOR: SOMANDO DESVANTAGENS, MULTIPLICANDO DESIGUALDADES?}

\section{Felícia Picanço}

Palavras-chave: Desigualdade; Ensino superior; Jovens; Cor/raça.

Nas últimas décadas, o Brasil experimentou a crescente expansão do acesso à educação nos diversos níveis acompanhada por um conjunto de políticas públicas e programas sociais de incentivo a ampliação de vagas e do ingresso dos mais pobres, egressos de escolas públicas e da população negra e indígena. $\mathrm{O}$ artigo tem como objetivo analisar em que medida essa expansão alterou a desigualdade de chances dos jovens (18 a 29 anos) brancos e negros, com maior e menor renda no acesso ao ensino superior no Brasil a partir dos dados da Pesquisa Nacional por Amostra de Domicílios.

\section{YOUNGSTERS BY COLOR AND INCOME IN THE ACCESS TO HIGHER EDUCATION: ADDING DISADVANTAGES, MULTIPLYING INEQUALITIES}

\section{Felícia Picanço}

Keywords: Inequality; Higher Education; youngsters; Color/Race.

In the last decades Brazil experienced a growing educational expansion accompanied by a set of public policies and social programs of incentive to increase enrollment of the poorest, public school graduates and the black and indigenous populations. Using data from the National Household Sample Survey (PNAD), the article aims to analyze to what extent this expansion changed the unequal chances of young people (18-29 years), white and black, with higher and lower income, in the access to higher education in Brazil.

\section{L'ACCÈS DE LA JEUNESSE À L.ENSEIGNEMENT SUPÉRIEUR SUIVANT LA COULEUR DE LA PEAU ET LE REVENU: L'ADDITION D'INCONVÉNIENTS ET LA MULTIPLICATION DES INÉGALITÉS ?}

\section{Felícia Picanço}

Mots-clés: Inégalités; Enseignement supérieur; Jeunes; Couleur/race.

Au cours des dernières décennies, le Brésil a connu l'expansion croissante de l'accès à l'éducation à différents niveaux accompagnés par un ensemble de politiques publiques et des programmes sociaux d'incitation à l'accroissement de la fréquentation et de la scolarisation des plus pauvres, des étudiants issus d'écoles publiques et de la population noire et autochtone. L'article a pour but l'analyse de cette expansion et de la mesure du changement de l'inégalité d'opportunités des jeunes (18-29 ans) blancs et noirs, avec des revenus plus élevés ainsi que des plus bas, dans l'accès à l'enseignement supérieur au Brésil à partir des données de l'Enquête Nationale Auprès des Ménages. 